Prepared in cooperation with the Bureau of Reclamation

Estimation of Dissolved-Solids Concentrations Using Continuous Water-Quality Monitoring and Regression Models at Four Sites in the Yuma Area, Arizona and California, January 2017 through March 2019

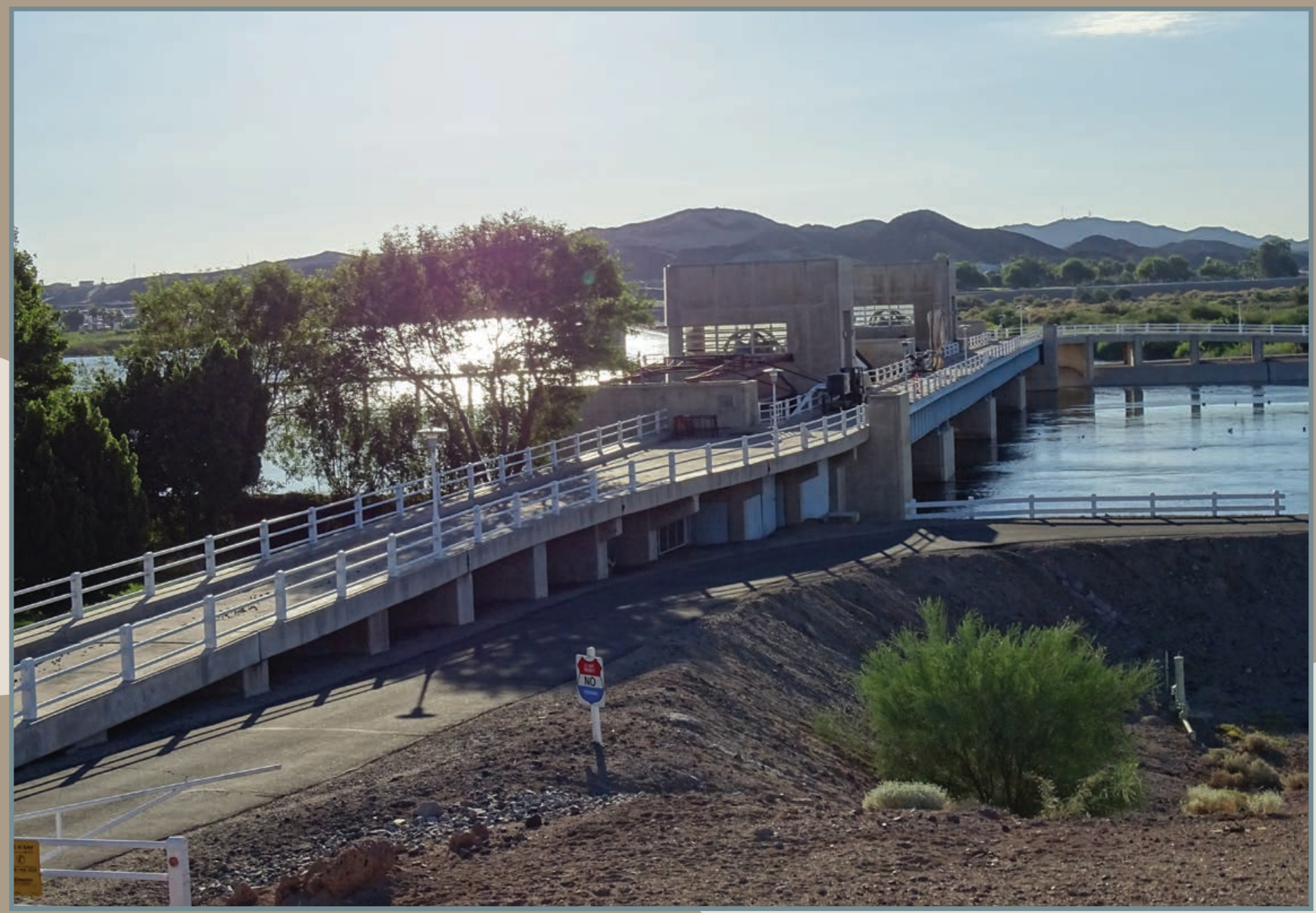

Scientific Investigations Report 2021-5080

U.S. Department of the Interior U.S. Geological Survey 
Cover: Photograph of the Colorado River at Imperial Dam northeast of Yuma, Arizona. Gates in the foreground supply Colorado River water to desilting ponds before being diverted to the All American Canal. U.S. Geological Survey photograph by Alissa Coes. 


\section{Estimation of Dissolved-Solids Concentrations Using Continuous Water-Quality Monitoring and Regression Models at Four Sites in the Yuma Area, Arizona and California, January 2017 through March 2019}

By Jay R. Cederberg, Nicholas V. Paretti, Alissa L. Coes, Edyth Hermosillo, and Lucia Andrade

Prepared in cooperation with the Bureau of Reclamation

Scientific Investigations Report 2021-5080 


\section{U.S. Geological Survey, Reston, Virginia: 2021}

For more information on the USGS — the Federal source for science about the Earth, its natural and living resources, natural hazards, and the environment-visit https://www.usgs.gov or call 1-888-ASK-USGS.

For an overview of USGS information products, including maps, imagery, and publications, visit https://store.usgs.gov.

Any use of trade, firm, or product names is for descriptive purposes only and does not imply endorsement by the U.S. Government.

Although this information product, for the most part, is in the public domain, it also may contain copyrighted materials as noted in the text. Permission to reproduce copyrighted items must be secured from the copyright owner.

Suggested citation:

Cederberg, J.R., Paretti, N.V., Coes, A.L., Hermosillo, E., Andrade, L., 2021, Estimation of dissolved-solids concentrations using continuous water-quality monitoring and regression models at four sites in the Yuma area, Arizona and California, January 2017 through March 2019: U.S. Geological Survey Scientific Investigations Report 2021-5080, 26 p., https://doi.org/10.3133/SIR20215080.

Associated data for this publication:

Hermosillo, E., and Cederberg, J.R., 2019, Supplemental streamflow, quality-assurance, and dissolved-solids concentration datasets used for regression model development at four sites in the Yuma area, Arizona and California, January 2017 through March 2019: U.S. Geological Survey data release, https://doi.org/10.5066/p9SMK908.

ISSN 2328-0328 (online) 


\section{Acknowledgments}

Anna Morales of the International Boundary and Water Commission provided instantaneous and daily mean streamflow data. 


\section{Contents}

Acknowledgments ........................................................................................................................

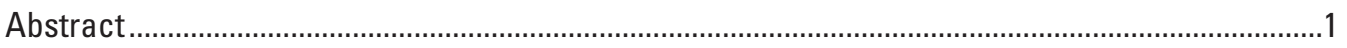

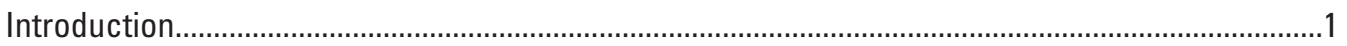

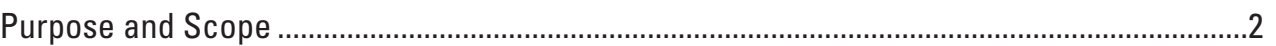

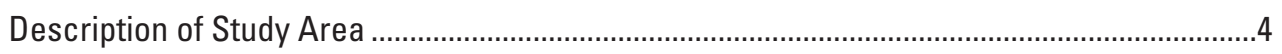

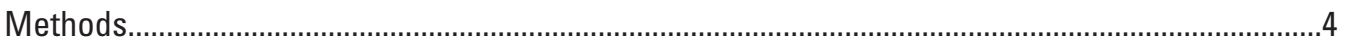

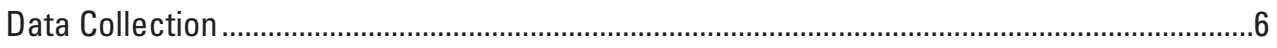

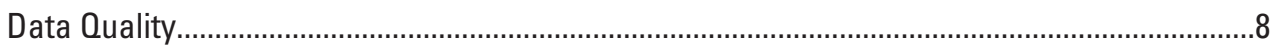

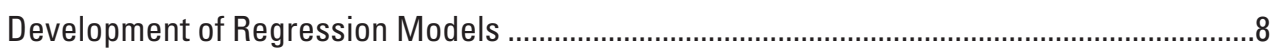

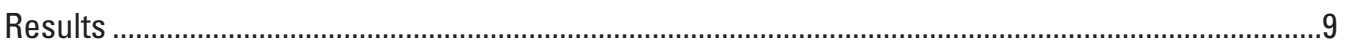

Colorado River above Imperial Dam, Arizona-California .........................................................12

Colorado River below Cooper Wasteway............................................................................15

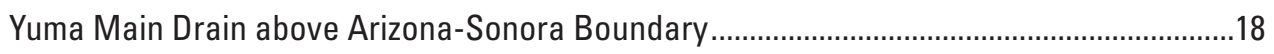

242 Lateral above Main Drain at Arizona-Sonora Boundary ....................................................21

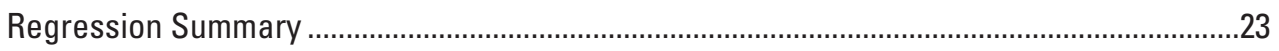

Summary

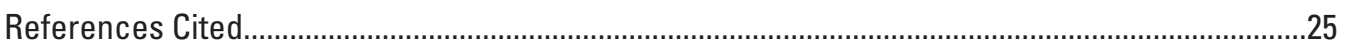

\section{Figures}

1. Map of study area and location of data collection sites in the Yuma, Arizona, area between Imperial Dam and the southerly international boundary between the United States and Mexico, January 2017 to March 2019.................................................3

2. U.S. Geological Survey photographs of four water-quality monitoring sites ....................5

3. U.S. Geological Survey photograph of the water-quality monitor installed at station 09429490

4. Trilinear diagram showing major-ion chemistry of waters at four stations in the Yuma, Arizona, area between Imperial Dam and the United States-Mexico southerly international boundary, January 2017 to March 2019

5. Scatterplot showing the relation of specific conductance and dissolved-solids concentration of waters at four sites in the Yuma, Arizona, area between Imperial Dam and the United States-Mexico southerly international boundary, January 2017 to March 2019

6. Boxplot diagrams comparing dissolved-solids concentrations at four sites in the Yuma, Arizona, area from January 2017 to March 2019

7. Line graphs showing streamflow, specific conductance, and water temperature at station 09429490

8. Line graph showing modeled continuous dissolved-solids concentration, sampled dissolved-solids concentration, and streamflow at station 09429490

9. Line graph showing percentage of time specific conductance and streamflow were equaled or exceeded at station 09429490

10. Line graphs showing measured specific conductance, adjusted mean specific conductance, and sampled specific conductance at station 09522005 compared to streamflow at 09527000 from January 2017 to March 2019. 
11. Line graphs showing specific conductance and water temperature at station number 09522005 compared to streamflow at 09527000 and 09522000 for the period of study from January 2017 to March 2019.

12. Line graph showing modeled continuous dissolved-solids concentration and sampled dissolved-solids concentration at station 09522005 and streamflow at station 09522000 .

13. Line graph showing percentage of time specific conductance was equaled or exceeded at station 09522005 and streamflow was equaled or exceeded at station 09522000

14. Line graphs showing streamflow, specific conductance, and water temperature at station 09534000 .

15. Line graph showing modeled continuous dissolved-solids concentration, sampled dissolved-solids concentration, and streamflow at station 09534000.

16. Line graph showing percentage of time specific conductance and streamflow were equaled or exceeded at station 09534000

17. Line graphs showing streamflow, specific conductance, and water temperature at station 09534550

18. Line graph showing modeled continuous dissolved-solids concentration, sampled dissolved-solids concentration, and streamflow at station 09534550

19. Line graph showing percentage of time specific conductance and streamflow were equaled or exceeded at station 09534550 .

20. Plots of modeled versus observed regression with 1:1 line and plots of modeled versus observed residuals at stations $09429490,09522005,09534000$, and $09534550 \ldots . . .24$

\section{Tables}

1. List of continuous in-stream monitoring of water temperature, specific conductance, and computed dissolved-solids concentrations at four sites in the Yuma, Arizona, area between Imperial Dam and the United States-Mexico southerly international boundary, January 2017 to March 2019.

2. List of constituents analyzed for in discrete samples collected at four water-quality monitoring sites in the Lower Colorado River basin

3. List of constituents used for computing dissolved-solids concentrations in discrete samples at four sites in the Yuma, Arizona, area between Imperial Dam and the United States-Mexico southerly international boundary, January 2017 to March 2019

4. Regression models and summary statistics for estimating concentrations of dissolved solids in water at four stations in the Yuma, Arizona, area between Imperial Dam and the United States-Mexico southerly international boundary, January 2017 to March 2019

5. Regression model correlation statistics for estimating concentrations of dissolved solids in water at four stations in the Yuma, Arizona, area between Imperial Dam and the United States-Mexico southerly international boundary, January 2017 to March 2019 


\section{Conversion Factors}

U.S. customary units to International System of Units

\begin{tabular}{|c|c|c|}
\hline Multiply & By & To obtain \\
\hline \multicolumn{3}{|c|}{ Length } \\
\hline inch (in.) & 2.54 & centimeter $(\mathrm{cm})$ \\
\hline foot (ft) & 0.3048 & meter $(\mathrm{m})$ \\
\hline mile (mi) & 1.609 & kilometer $(\mathrm{km})$ \\
\hline \multicolumn{3}{|c|}{ Area } \\
\hline acre & 4,047 & square meter $\left(\mathrm{m}^{2}\right)$ \\
\hline acre & 0.004047 & square kilometer $\left(\mathrm{km}^{2}\right)$ \\
\hline square mile $\left(\mathrm{mi}^{2}\right)$ & 2.590 & square kilometer $\left(\mathrm{km}^{2}\right)$ \\
\hline \multicolumn{3}{|c|}{ Volume } \\
\hline gallon (gal) & 3.785 & liter $(\mathrm{L})$ \\
\hline cubic foot $\left(\mathrm{ft}^{3}\right)$ & 0.02832 & cubic meter $\left(\mathrm{m}^{3}\right)$ \\
\hline acre-foot (acre-ft) & 1,233 & cubic meter $\left(\mathrm{m}^{3}\right)$ \\
\hline \multicolumn{3}{|c|}{ Flow rate } \\
\hline acre-foot per day (acre-ft/d) & 0.01427 & cubic meter per second $\left(\mathrm{m}^{3} / \mathrm{s}\right)$ \\
\hline cubic foot per second $\left(\mathrm{ft}^{3} / \mathrm{s}\right)$ & 0.02832 & cubic meter per second $\left(\mathrm{m}^{3} / \mathrm{s}\right)$ \\
\hline
\end{tabular}

Temperature in degrees Celsius $\left({ }^{\circ} \mathrm{C}\right)$ may be converted to degrees Fahrenheit $\left({ }^{\circ} \mathrm{F}\right)$ as

$$
{ }^{\circ} \mathrm{F}=\left(1.8 \times{ }^{\circ} \mathrm{C}\right)+32 .
$$

Temperature in degrees Fahrenheit $\left({ }^{\circ} \mathrm{F}\right)$ may be converted to degrees Celsius $\left({ }^{\circ} \mathrm{C}\right)$ as

$$
{ }^{\circ} \mathrm{C}=\left({ }^{\circ} \mathrm{F}-32\right) / 1.8 \text {. }
$$

\section{Datum}

Horizontal coordinate information is referenced to the North American Datum of 1983 (NAD 83).

\section{Supplemental Information}

Specific conductance is given in microsiemens per centimeter at 25 degrees Celsius $\left(\mu \mathrm{S} / \mathrm{cm}\right.$ at $\left.25^{\circ} \mathrm{C}\right)$.

Concentrations of chemical constituents in water are given in either milligrams per liter (mg/L) or micrograms per liter ( $\mu \mathrm{g} / \mathrm{L})$. 


\section{Abbreviations}

$242 \mathrm{~L}$

242 lateral above Main Drain at Arizona-Sonora boundary

CRID

Colorado River above Imperial Dam, Arizona-California

CRCW

Colorado River below Cooper wasteway near Yuma, Arizona

EPA

U.S. Environmental Protection Agency

IBWC

International Boundary and Water Commission

NIB

northerly international boundary with Mexico

NWIS

National Water Information System

ppm

part per million

PRESS

predicted residual sum of squares

$\mathrm{R}^{2}$

coefficient of determination

Reclamation

Bureau of Reclamation

RMSE

root mean square error

RSD

relative standard deviation

SIB

southerly international boundary with Mexico

USGS

U.S. Geological Survey

YMD

Yuma Main Drain above Arizona-Sonora boundary

$\mu S$

microsiemens 



\title{
Estimation of Dissolved-Solids Concentrations Using Continuous Water-Quality Monitoring and Regression Models at Four Sites in the Yuma Area, Arizona and California, January 2017 through March 2019
}

\author{
By Jay R. Cederberg, Nicholas V. Paretti, Alissa L. Coes, Edyth Hermosillo, and Lucia Andrade
}

\section{Abstract}

Multiple linear regression models were developed to estimate dissolved-solids concentrations in water at four sites in the Yuma area between Imperial Dam, Arizona and California and the southerly international boundary with Mexico at San Luis, Arizona. Continuous and discrete water-quality data were collected at gaging stations in the Colorado River upstream from Imperial Dam, Arizona-California, the Colorado River below Cooper wasteway near Yuma, Arizona, the Yuma Main Drain above Arizona-Sonora, Mexico boundary, and the 242 lateral above Main Drain at the Arizona-Sonora boundary. Continuous specific conductance and water temperature data were collected at each site between January 2017 and March 2019. Bi-weekly to monthly dissolved-solids water samples were collected during the same period. Continuous specific conductance data collected at the Colorado River below Cooper wasteway were affected by poorly mixed streamflow during periods when the Pilot Knob Hydro-electric Plant was releasing water to the river. The continuous specific conductance data for the site downstream from Cooper wasteway were corrected using mean specific conductance values computed from crosssection measurements collected during site visits. Continuous specific conductance data were affected by sensor fouling issues at the 242 lateral site, and continued operation at the site would require more frequent visits for cleaning and service to ensure data quality.

During the study, instream specific conductance readings ranged from 966 to 3,030 microsiemens per centimeter $(\mu \mathrm{S} / \mathrm{cm})$ at 25 degrees Celsius. Computed dissolved-solids concentrations from discrete samples ranged from 690 to 2,580 milligrams per liter $(\mathrm{mg} / \mathrm{L})$. Dissolved-solids concentrations were estimated from regression models using the optimal relation between dissolved solids and environmental factors, such as specific conductance, water temperature, dissolved oxygen, streamflow, and seasonality. Specific conductance was the primary factor at all four sites and explained 87.6 to 94 percent of variation in dissolved solids. Water temperature, as an indicator of seasonality, was determined to be a statistically significant secondary factor at both the Colorado River above Imperial Dam and Colorado River below Cooper wasteway sites explaining an additional 6.9 and 2.1 percent of variation in dissolved solids, respectively. Regression models explained 87.6 to 96.9 percent of the variation in dissolved solids; the root mean square error in the modeled data ranged between about 6 and $27 \mathrm{mg} / \mathrm{L}$.

\section{Introduction}

The 1,450-mile long Colorado River drains 246,000 square miles $\left(\mathrm{mi}^{2}\right)$ of seven states in the United States and two states in Mexico, supports over 40 million people, supplies irrigation water for over 5.5 million acres of land, and provides more than 4,200 megawatts of hydroelectrical capacity for the Western United States (Colorado River Basin Water Supply and Demand Study Team, 2012; Colorado River Basin Salinity Control Forum, 2017). The river also supports Native American Indian tribes and natural resource lands including national wildlife refuges, park units, and recreation areas (Colorado River Basin Salinity Control Forum, 2017).

Lower Colorado River water arriving at Imperial Dam on the Arizona and California border about 20 miles north of Yuma, Arizona (Ariz.), supports agriculture, industry, and municipal uses in Arizona and California, and in the Mexican States of Baja California and Sonora (Colorado River Basin Water Supply and Demand Study Team, 2012). The Yuma area, as used in this report, begins at Imperial Dam, includes the flood plains of the Colorado and Gila Rivers and Yuma Mesa, and extends to the southerly international boundary with Mexico (Owen-Joyce and Raymond, 1996; fig. 1). Most of the Colorado River water arriving at Imperial Dam is diverted to canals for distribution in Southern California, the Yuma area, and for delivery to Mexico. The distribution is controlled by an extensive system of diversion dams, canals, and drains. Most of the streamflow in the river, as it approaches Morelos Dam on the border between the United States and Mexico, consists of return flows of irrigation water through wasteways, drains, and groundwater. Return flows from drains and groundwater to the Colorado River have a higher dissolvedsolids concentration than the river water arriving at Imperial Dam because of sorption of ions from the soils and sediment (Olmsted and others, 1973; Dickinson and others, 2006). The 
treaty relating to the Utilization of Waters of the Colorado and Tijuana Rivers and of the Rio Grande (the Water Treaty of 1944) between the United States and Mexico (Treaty Series 994, 59 Statute 1219) guarantees that 1.5 million acre-feet of Colorado River water are delivered to Mexico from the United States annually. The Binational Minute 242 agreement further states that the water delivered to Mexico upstream from Morelos Dam must have an annual mean salinity of no more than $115 \pm 30$ parts per million $(\mathrm{ppm})$ greater than the annual mean salinity of Colorado River water at Imperial Dam (International Boundary and Water Commission, 1973). Units of salinity, in ppm, are equivalent to the units of dissolved solids, in $\mathrm{mg} / \mathrm{L}$, for concentrations less than 7,000 $\mathrm{mg} / \mathrm{L}$. Salinity, herein referred to as dissolved solids, is a measure of the ionic concentration of dissolved minerals in water and is computed as the summation of the major cations and anions dissolved in water.

The Bureau of Reclamation, herein referred to as Reclamation, is responsible for completing water deliveries to Mexico that meet both the quantity and water-quality criteria set forth by the Water Treaty of 1944 and Minute Agreement 242. Reclamation monitors dissolved-solids concentrations in waters delivered to Mexico by collecting periodic water samples at stations 09429490 (Colorado River above Imperial Dam, Arizona-California), 09522000 (Colorado River at the northern international boundary [NIB], above Morelos Dam, Arizona), and 09534000 (Yuma Main Drain above Arizona-Sonora boundary). The samples are analyzed and dissolved-solids concentrations are reported back to Reclamation in a process that takes four to six weeks to complete. The binational agreement, Minute 323, established in September 2017, states that the Minute 323 Salinity Work Group will work to modernize salinity monitoring equipment and develop reporting tools to make real-time data available to operators in both countries (International Boundary and Water Commission, 2017). The U.S. Geological Survey (USGS), working in cooperation with Reclamation, developed surrogate regression models to estimate dissolved-solids concentrations from specific conductance data collected at four sites within the Yuma area. Near real-time data allow water managers to make informed decisions regarding management of dissolved solids in waters delivered from the Colorado River.

\section{Purpose and Scope}

The purpose of this study was to develop site-specific numerical relations of continuously monitored specific conductance and discretely measured dissolved-solids concentrations at four sites between Imperial Dam and the southerly international boundary between the United States and Mexico (SIB) in order to use specific conductance as a surrogate for dissolved-solids concentrations. Specific conductance can be continuously recorded and can be used in conjunction with the surrogate models to provide real-time estimates of dissolvedsolids concentration data through the USGS National Water Information System (NWIS) data portal (https://waterdata. usgs.gov/az/nwis/current/?type=quality\&group_key=NONE). These data provide resource managers with the information necessary to make timely informed decisions based on up-todate estimated dissolved-solids concentrations. This report describes the methods and results of the data collection and regression model development relating continuously recorded specific conductance to discrete dissolved-solids concentrations. Data were collected at four sites in the Yuma area; two of the sites are located on the lower Colorado River, one site is located at Imperial Dam, and one site is located 0.5 mile upstream from Morelos Dam near the NIB; and two sites, one drain and one canal, are located at the SIB at San Luis, Ariz. (fig. 1; table 1).

Table 1. List of continuous in-stream monitoring of water temperature, specific conductance, and computed dissolved-solids concentrations at four sites in the Yuma, Arizona, area between Imperial Dam and the United States-Mexico southerly international boundary, January 2017 to March 2019.

[Station names are those listed in the USGS National Water Information System (U.S. Geological Survey, 2019) followed by station abbreviation used in this report. Latitude and longitude data referenced to North American Datum 1983. Ariz., Arizona; Calif., California; USGS, U.S. Geological Survey]

\begin{tabular}{|c|c|c|c|c|c|c|}
\hline $\begin{array}{l}\text { Map } \\
\text { identifier }\end{array}$ & $\begin{array}{l}\text { USGS station } \\
\text { number }\end{array}$ & Station name & $\begin{array}{l}\text { Primary sources of } \\
\text { water at site }\end{array}$ & $\begin{array}{c}\text { Latitude, in } \\
\text { decimal degrees }\end{array}$ & $\begin{array}{l}\text { Longitude, in } \\
\text { decimal degrees }\end{array}$ & $\begin{array}{l}\text { Period of } \\
\text { record }\end{array}$ \\
\hline 1 & 09429490 & $\begin{array}{l}\text { Colorado River above Imperial } \\
\text { Dam, Ariz.-Calif. (CRID) }\end{array}$ & $\begin{array}{l}\text { Basin water collected at } \\
\text { Imperial Dam }\end{array}$ & 32.88494 & 114.46811 & $\begin{array}{c}1 / 30 / 17 \text { to } \\
3 / 5 / 19\end{array}$ \\
\hline 2 & 09522005 & $\begin{array}{l}\text { Colorado River below Cooper } \\
\text { wasteway near Yuma, Ariz. } \\
(\mathrm{CRCW})\end{array}$ & $\begin{array}{l}\text { Basin water and } \\
\text { irrigation return flows }\end{array}$ & 32.71222 & 114.72222 & $\begin{array}{c}1 / 25 / 17 \text { to } \\
3 / 5 / 19\end{array}$ \\
\hline 4 & 09534550 & $\begin{array}{l}242 \text { lateral above Main Drain } \\
\text { at Ariz. -Sonora boundary } \\
(242 \mathrm{~L})\end{array}$ & $\begin{array}{l}\text { Groundwater withdrawals } \\
\text { from wells in the } 242 \\
\text { well field }\end{array}$ & 32.48694 & 114.78722 & $\begin{array}{c}1 / 26 / 17 \text { to } \\
3 / 5 / 19\end{array}$ \\
\hline
\end{tabular}




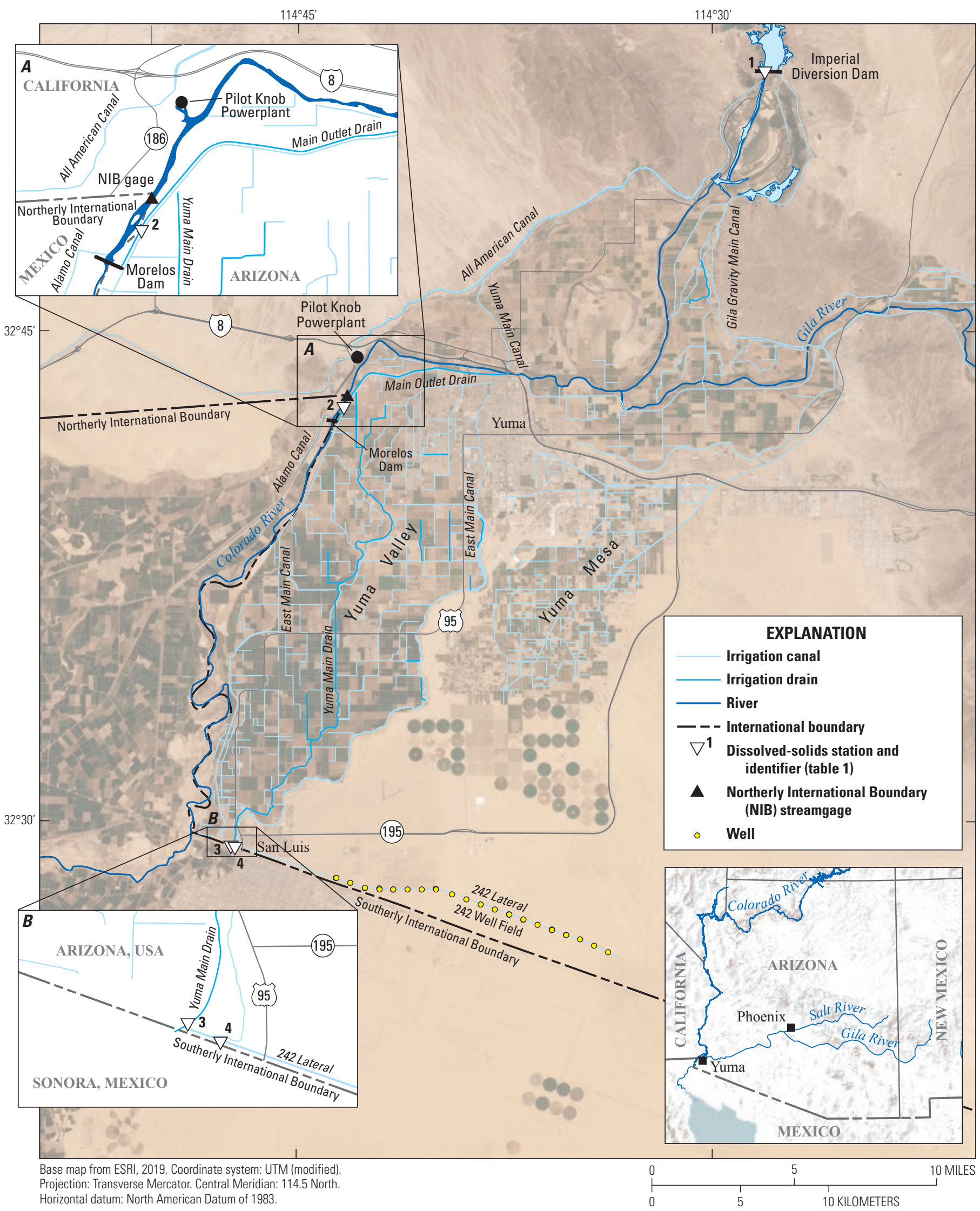

Figure 1. Map of study area and location of data collection sites in the Yuma, Arizona, area between Imperial Dam and the southerly international boundary between the United States and Mexico, January 2017 to March 2019. See table 1 for dissolved-solids station information. 


\section{Description of Study Area}

The four monitoring sites in this study are located within the Yuma area which extends from the north at Imperial Dam, about 20 miles north of Yuma, Ariz., to the south at the southerly international boundary with Mexico near San Luis, Ariz. (fig. 1). Streamflow arriving at Imperial Dam is almost entirely from the Colorado River with minor inputs from small ephemeral drainages. Imperial Dam is a concrete diversion structure located 18 miles north of Yuma that diverts Colorado River water to the All American Canal and the Gila Gravity Main Canal (International Boundary and Water Commission, 2006). The All American Canal head gates are located adjacent to the west abutment of the dam in California. Water diverted at Imperial Dam through the All American Canal for use in Arizona and California first passes through one of three desilting basins, which are used to remove sand and silt material (Imperial Irrigation District, 2019). The All American Canal delivers water to the Yuma area through numerous small canals that serve irrigated lands on the western side of the Colorado River and through the larger Yuma Main Canal that serves the Yuma Valley to the south of the city of Yuma. The Pilot Knob Hydro-electric Power Plant and Wasteway is the last diversion from the All American Canal for the Yuma area before the canal continues west along the NIB for distribution in California. Flow from the Pilot Knob Hydro-electric Plant is returned to the Colorado River directly downstream from the powerplant outlet, which is located about 1 mile upstream from the Colorado River at the NIB near Yuma, Ariz., streamgage. The Gila Gravity Main Canal head gates are located along the east abutment of the Imperial Dam in Arizona. One desilting basin removes the sand from the water before it enters the Gila Gravity Main Canal, which serves an area north of the Yuma Valley.

The Colorado River downstream from the Imperial Dam flows southward 9.9 miles to the mouth of the Gila River. The Gila River, with a watershed size of nearly 60,000 square miles, is tributary to the Colorado River but generally has negligible natural streamflow in the channel at the confluence caused by dams and irrigation diversions upstream from the Yuma area. Significant streamflow in the Gila River general only occurs during intense summer monsoon thunderstorms or sustained winter precipitation events, both of which are rare in the lower Colorado River Basin where mean annual precipitation in Yuma, Ariz., is only 3.56 inches (Phoenix, Arizona Weather Forecast Office, 2019). Downstream from the Gila River confluence, the Colorado River continues westward 11.2 miles to Pilot Knob Mountain and then south 1 mile to the point where the NIB intersects the river, between California and Baja California, Mexico. The International Boundary and Water Commission (IBWC) operates the Colorado River at NIB above Morelos Dam streamgage station 09522000. The gage is the official accounting gage for water delivered to Mexico at Morelos Dam, 1 mile downstream from the gage. The river continues to flow southward to Morelos Dam where most of the Colorado River remaining in the channel is diverted into the Alamo Canal in Mexico. South of Morelos Dam, the natural channel of the Colorado River forms the international boundary between the United States and Mexico for about 20.6 miles where the SIB intersects the river channel between Arizona and Sonora. From this point the river channel continues southward about 90 miles to the Gulf of California.

In accordance with Article 10 of the Water Treaty of 1944, waters of the Colorado River may be diverted to the All American Canal at Imperial Dam for delivery to Mexico in the Alamo Canal through Morelos Dam (1.1 miles downstream from NIB), the principal diversion structure on the Colorado River for Mexico. Almost all Colorado River waters diverted to Mexico have been diverted to the Alamo Canal at Morelos Dam, which was completed and placed in operation on November 8, 1950. The last wasteway returning water to the Colorado River upstream from Morelos Dam is Cooper wasteway, which is located 0.5 mile downstream from the NIB and 0.6 mile upstream from Morelos Dam. This wasteway infrequently discharges unused irrigation water back into the Colorado River.

Downstream from Imperial Dam, water is returned to the Colorado River principally from unused irrigation and drainage water from irrigated lands in the United States. Drainage waters include surface water sources (drains) and diffuse groundwater inputs.

The Yuma Main Drain collects drainage water within the Yuma Valley south of the city of Yuma and flows south to SIB at San Luis, Ariz. Drain water is pumped through four discharge pipes at the boundary pumping plant located about 200 feet (ft) north of the SIB near San Luis and 1.3 miles east of the Colorado River. Pumped water is delivered to Mexico through the Sanchez Canal.

The 242 well field consists of 21 groundwater-pumping wells located on the United States side of SIB on the Yuma Mesa east of San Luis, Ariz. The purpose of the well field is to capture groundwater that flows south from the Yuma area into Mexico and use it for water deliveries to Mexico. The groundwater pumped from the well field is collected and conveyed through the concrete lined 242 lateral. The 242 lateral flows into the Yuma Main Drain directly above the SIB.

\section{Methods}

Multiparameter water-quality monitors equipped with specific conductance and water temperature sensors were installed and operated at four sites in the Yuma area between Imperial Dam and the United States-Mexico SIB during January 2017 through March 2019 (figs. 2 and 3). Each site was connected to a satellite transmitter to allow for hourly transmission of data. Additionally, about 36 discrete waterquality samples were collected at each site over the same time period. Four specific site locations were selected cooperatively with Reclamation and are shown in figure 1 and table 1: (1) 09429490 (Colorado River above Imperial Dam [CRID]), (2) 09522005 (Colorado River below Cooper wasteway near 

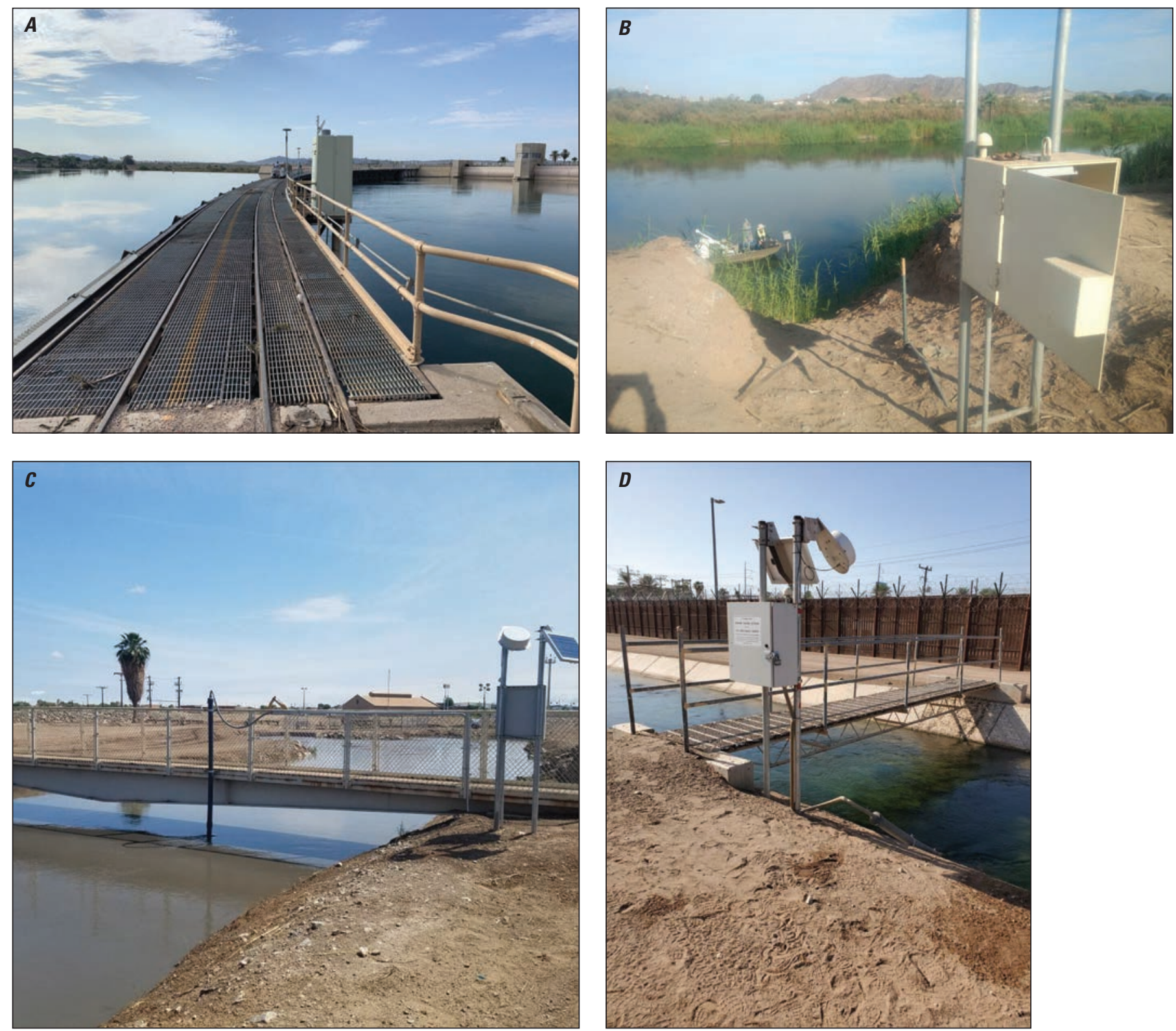

Figure 2. U.S. Geological Survey photographs of four water-quality monitoring sites: $A, 09429490$ (Colorado River above Imperial Dam, Arizona-California); B, 09522005 (Colorado River below Cooper wasteway near Yuma, Arizona); $C, 09534000$ (Yuma Main Drain above Arizona-Sonora boundary); D, 09534550 (242 lateral above Main Drain at ArizonaSonora boundary).

Yuma, Ariz. [CRCW]), (3) 09534550 (Yuma Main Drain above Arizona-Sonora boundary [YMD]), and (4) 09534550 (242 lateral above Main Drain at Arizona-Sonora boundary [242L]). CRID, YMD, and 242L were colocated with a streamgage station operated by either Reclamation or IBWC. The site at CRCW was located 0.6 mile downstream from streamflow-gaging station 09522000 to account for unused irrigation water discharging to the Colorado River from
Cooper wasteway located 0.5 mile below Colorado River at NIB. Colorado River at NIB is a long-term sampling location that has a period of record for dissolved solids that extends back to the early 1960s and has over 1,500 samples collected and analyzed (station 09522000 , U.S. Geological Survey, 2019). This location was used to compare with CRCW and check dissolved-solids patterns, as well as validate the dissolved-solids model. 


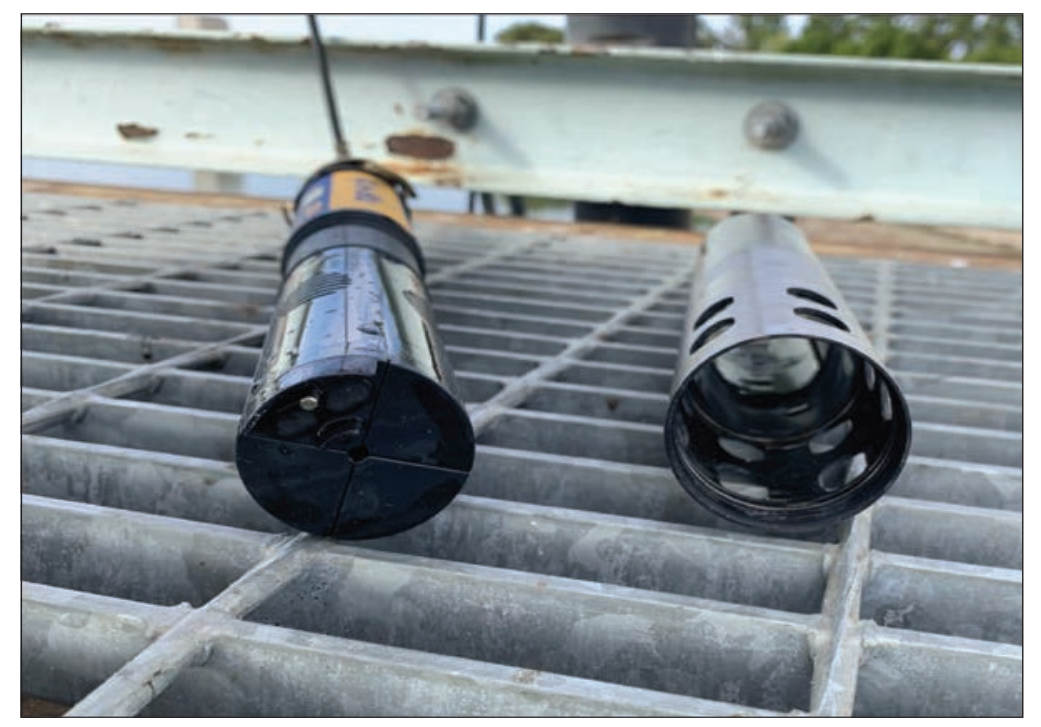

Figure 3. U.S. Geological Survey photograph of the water-quality monitor installed at station 09429490 (Colorado River above Imperial Dam, Arizona-California).

\section{Data Collection}

Specific-conductance and water temperature sensors were operated following standard USGS protocols (Pellerin and others, 2013; Wagner and others, 2006). Specific conductance is a measure of water's ability to conduct an electrical current and is related to the concentration of ionized substances in water (Hem, 1985). Specific conductance and water temperature data were measured and recorded in 15-minute intervals and transmitted hourly to the USGS National Water Information System. Real-time data for each site are available at https://waterdata.usgs.gov/az/nwis/nwis. Each station was visited for scheduled maintenance on a monthly or additional basis as required. The monitors at CRID and $\mathrm{CRCW}$ required a boat to access the sensors to perform cleaning and calibration procedures. The monitors at YMD and 242L were accessed from a pedestrian walkway. During each visit, the specific conductance and water temperature sensors were checked for fouling and cleaned. Additionally, the specific conductance sensor was checked for calibration drift using specific conductance standard solutions purchased from the USGS National Water Quality Laboratory. The specific conductance sensor was recalibrated if the difference between the sensor and the standard exceeded 3 percent. A field meter equipped with water temperature and specific conductance sensors was calibrated before each visit and used as an independent reading for comparison purposes. Time-series data were processed, checked, and reviewed using methods described in Rasmussen and others (2009).

Cross-section survey data of water temperature and specific conductance were collected during each site visit to verify that the sensor location was representative of conditions throughout the channel. Cross-section readings consisted of a single measurement collected at a depth of about midway between the channel bottom and water surface at five separate verticals across the stream cross section. The vertical values were averaged and compared to the monitor reading collected at about the same time. Cross-section data were well within the allowable 10 percent difference from monitor readings as recommended in Wagner and others (2006) for CRID, YMD, and $242 \mathrm{~L}$ indicating the monitor location was appropriate at these sites. At CRCW, the amount of variation in specific conductance readings in the cross section was significantly greater than 10 percent on most occasions. Specificconductance readings were consistently higher at the east edge of water where the monitor was installed. For this station, the location of the sensor was not representative of the entire, integrated stream, but given the sampling requirements and access restrictions for this site, moving the sensor was not an option. Conductivity data for $\mathrm{CRCW}$ were corrected using cross-section, streamflow, and discrete water-quality data. The correction is discussed further in the Results section.

Discrete water-quality samples were collected monthly during the study. Additional samples were collected on a biweekly basis to capture a wider range of streamflow conditions that can be affected by seasonal changes, agricultural demands, and treaty stipulations. Discrete samples were collected throughout the range of hydrologic and seasonal conditions. Sampling conditions varied from site to site, but water-quality samples were collected using isokinetic, depth-integrated methods in accordance with the USGS National Field Manual (U.S. Geological Survey, 2012). DH-95 or DH-81 samplers and a cleaned sample bottle were used for all samples. Subsamples were composited in a polyethylene churn then filtered using a 0.45 -micrometer capsule filter. Samples were processed and shipped to the USGS National Water Quality Laboratory in Denver, Colo., for analysis. Water samples were analyzed for dissolved major ions and nutrients 
(table 2) at the National Water Quality Laboratory using methods described in Fishman (1993), Fishman and Friedman (1989), and Patton and Kryskalla (2011).

"Salinity" is defined as the concentration of dissolved solids computed as the summation of the major chemical constituents in a sample. For comparability of data collected by both the United States and Mexico, Minute 242 defines salinity as the summation of 11 dissolved constituents and their associated conversion factors (table 3). Standard dissolved-solids computation by USGS utilizes the same chemical analytes but uses different factors for bicarbonate and nitrate as N. All USGS dissolved-solids data are archived in the USGS National Water Information System database (U.S. Geological Survey, 2019) and all dissolved-solids data computed using Reclamation's method are published in Hermosillo and Cederberg (2019). To provide consistency with Reclamation, the analysis and regression models described in this document utilize Reclamation's method of computation for dissolved solids.

Table 2. List of constituents analyzed for in discrete samples collected at four water-quality monitoring sites in the Lower Colorado River basin.

$\left[\mathrm{CaCO}_{3}\right.$, calcium carbonate; $\mathrm{mg} / \mathrm{L}$, milligram per liter; $\mathrm{NH}_{3}$, ammonia; $\mathrm{NH}_{4}^{+}$, ammonium; $\mathrm{SiO}_{2}$, silica; USGS, U.S. Geological Survey]

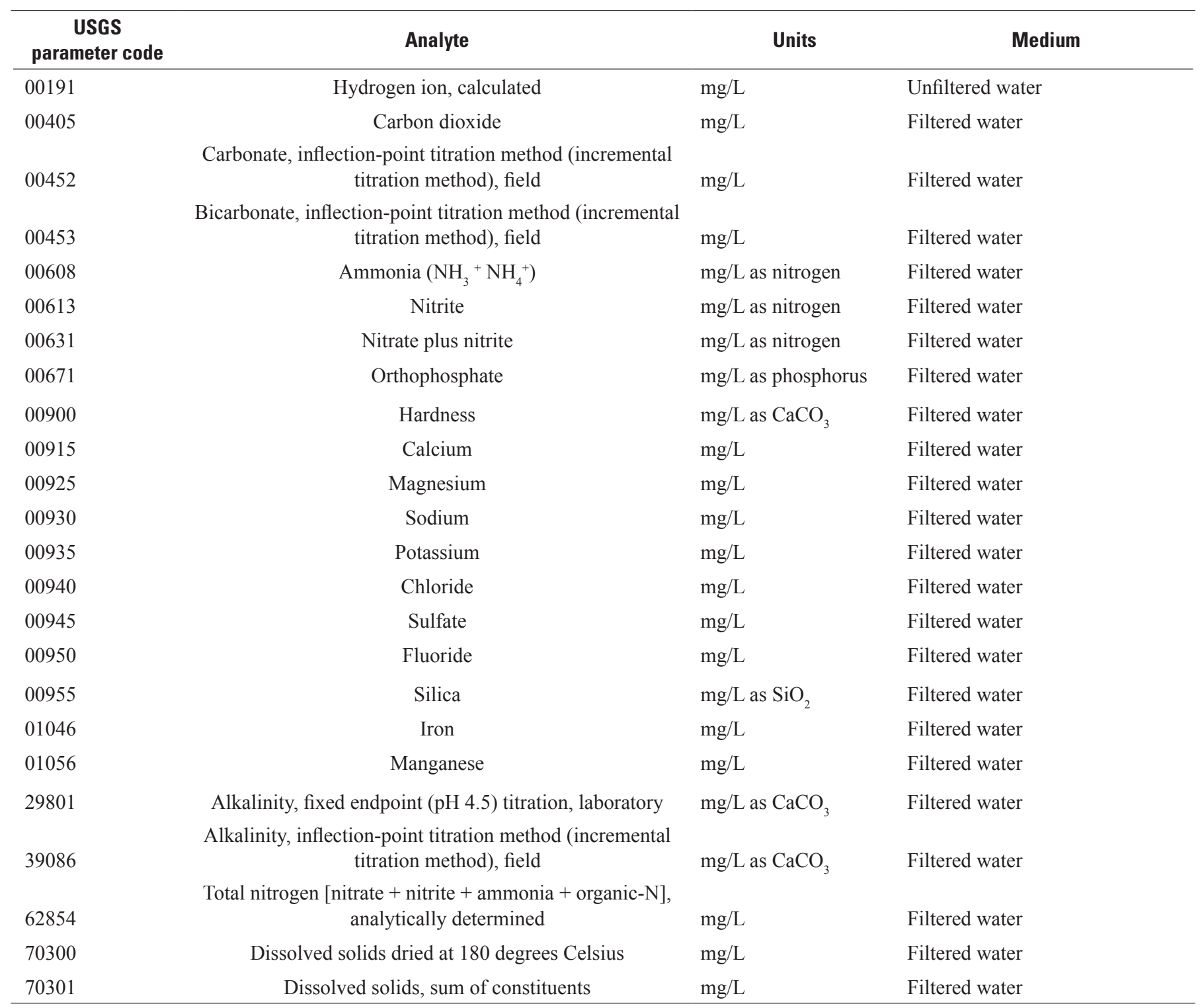


Table 3. List of constituents used for computing dissolved-solids concentrations in discrete samples at four sites in the Yuma, Arizona, area between Imperial Dam and the United States-Mexico southerly international boundary, January 2017 to March 2019.

[Reclamation, Bureau of Reclamation; $\mathrm{SiO}_{2}$, silica; USGS, U.S. Geological Survey]

\begin{tabular}{cccc}
\hline USGS parameter code & Analyte & USGS conversion factor & Reclamation conversion factor \\
\hline 00453 & $\begin{array}{c}\text { Bicarbonate, inflection-point titration method } \\
\text { (incremental titration method), field }\end{array}$ & 0.49175 & 0.493 \\
00631 & Nitrate plus nitrite & 4.4268 & 4.43 \\
00915 & Calcium & 1 & 1 \\
00925 & Magnesium & 1 & 1 \\
00930 & Sodium & 1 & 1 \\
00935 & Potassium & 1 & 1 \\
00940 & Chloride & 1 & 1 \\
00945 & Sulfate & 1 & 1 \\
00950 & Fluoride & 1 & 1 \\
00955 & Silica as $\mathrm{SiO}_{2}$ & 1 & 1 \\
\hline
\end{tabular}

\section{Data Quality}

Blank samples are samples prepared with water that is intended to be free of measurable concentrations of the constituents that will be analyzed by the laboratory and are used to estimate the positive bias caused by contamination (Mueller and others, 2015). Field blanks document the frequency and magnitude of contamination in environmental samples for all or some part(s) of the sample collection and analysis process. There were 28 field blank samples collected by the USGS at the 4 study sites between January 2017 and March 2019 (Hermosillo and Cederberg, 2019). One field blank sample had a calcium detection, two had chloride detections, two had sulfate detections, and eight had silica detections. For 28 blank samples, the upper confidence limit is 95 percent that potential contamination is no greater than the highest concentration detected in at least 90 percent of the samples. The highest concentrations detected in the blanks were $0.04 \mathrm{mg} / \mathrm{L}$ for calcium, $0.06 \mathrm{mg} / \mathrm{L}$ for chloride, $0.02 \mathrm{mg} / \mathrm{L}$ for sulfate, and $0.05 \mathrm{mg} / \mathrm{L}$ for silica; all concentrations in the blank samples were 2 to 4 orders of magnitude less than the lowest concentrations in the environmental samples. The field blanks indicate, therefore, that there are acceptably low levels of bias affecting the environmental concentrations for these constituents, and by extension, the dissolved-solids concentrations.

Replicate samples are two or more water samples that are collected, prepared, and analyzed in the same manner such that they are considered to be essentially identical, and are used to estimate the variability of analytical results inherently related to the environment, sampling procedures, and laboratory procedures (Mueller and others, 2015). There were 32 dissolved-solids replicate-sample pairs collected by the USGS at the 4 study sites between January 2017 and March 2019 (Hermosillo and Cederberg, 2019). The relative standard deviation (RSD) of the replicate-sample pairs, defined as the ratio (in percent) of standard deviation to mean concentration, is generally uniform over the range of mean dissolved-solids concentrations. The RSD of the replicate-sample pairs ranged from 0 to 5.3 percent, with only 2 replicate-sample pairs having RSDs greater than 2 percent. Because the RSD is generally uniform over the range of mean dissolved solids, variability can be estimated as the mean RSD of 0.8 percent. The field replicate data indicate that there are acceptably low levels of variability affecting the environmental dissolvedsolids data.

\section{Development of Regression Models}

Using many discrete measures, a statistical model can be used to combine continuous and discrete water sample data at gages, so that constituent concentrations can be continuously computed (Shoda and others, 2015). Concentrations from laboratory analysis and corresponding values from in-stream instruments are combined to develop a statistical regression surrogate model for characteristics of streamflow that can be predicted. The model computes real-time concentrations based on continuous in-stream sensor readings of another, more easily measured value (surrogate).

Regression surrogate models were developed using concurrent measurements of discrete and continuous waterquality data collected from January 2017 through March 2019. Regression models were developed following methods described in Rasmussen and others (2009) and Helsel and others (2020). Ordinary least-squares regression was used to evaluate and determine the optimal continuous water-quality parameters (explanatory variables) to be used as surrogates for predicting discrete measures of dissolved solids (response variable). The functional form of a multiple-linear regression equation is:

$$
y_{-} i=\beta_{-} 0+\beta_{-} 1 x_{-} 1+\beta_{-} 2 x+\cdots+\beta_{-} n x_{-} n+\delta_{-} i
$$


where

$$
\begin{aligned}
& y_{-} i \quad \text { is the response variable (dissolved-solids } \\
& \text { concentration) for station } i \text {; } \\
& x \_1 \text { to } x \_n \quad \text { are the } n \text { explanatory variables (specific } \\
& \text { conductance; water temperature) for } \\
& \text { station } i \text {; } \\
& \beta \_0 \text { to } \beta \_n \quad \text { are the } n+1 \text { regression model coefficients; } \\
& \text { and } \\
& \delta \_i \quad \text { is the model error (difference between the } \\
& \text { observed concentration and the predicted } \\
& \text { concentration) for station } i \text {. }
\end{aligned}
$$

Ordinary-least-squares regression assumes that the dissolved-solids measurements are independent. Explanatory variables (water temperature, $\mathrm{pH}$, dissolved oxygen, specific conductance, streamflow, and monthly seasonality) were evaluated in a forward stepwise multiple linear regression procedure in JMP, version 12 software (SAS Institute, Inc., 2015). Significant parameters that most improved the model were selected by using the minimum Bayesian information criterion as a stopping rule to choose the best model. The Bayesian information criterion introduces a penalty term for the number of parameters in the model; the penalty term is larger in Bayesian information criterion than in Akaike information criterion.

Several diagnostics described in Rasmussen and others (2009) were used to evaluate models. The variance inflation factor was evaluated to avoid multicollinearity in the explanatory variable selection process. It measures the degree to which the variance of the coefficient of determination for a variable is increased because of correlation between that variable and other variables selected in the model. The Durbin-Watson statistic was used to test whether the errors have first-order autocorrelation. It is useful for time-series data when errors are correlated across time.

Other regression statistics are useful in evaluating models. The adjusted coefficient of determination $\left(\mathrm{R}^{2}\right)$ describes how much of the variability is explained in the model. The root mean square error indicates the range in uncertainty associated with each regression equation. The $\mathrm{p}$-values indicate significant variables based on the t-statistics that likely should be included in the final model form. The predicted residual error sum of squares (PRESS) statistic provides a measure of the crossvalidation summary of the model fit to a sample of observations not used to estimate the model (leave-one-out cross-validation). In general, the smaller the PRESS statistic, the better the model's predictive ability (Helsel and others, 2020). Plots of the observed versus the predicted values from the model and the variance of the residuals plotted against the model predicted values were visually assessed. These plots can help to identify issues with normality and transformations made to the datasets prior to regression analysis. Additional plots highlight differences among predicted and observed values, residuals by season, and residuals by year. Prediction intervals were developed for each model, following methods from Helsel and others (2020), to define the range of values within which there is 95 -percent certainty that the true value occurs.

\section{Results}

Mean dissolved-solids concentrations were lowest at the most upstream site located at CRID (690 mg/L; table 4) and highest at YMD (1,180 mg/L). General chemistry and dissolved solids were more similar in the main Colorado River sites (CRID and CRCW) than the canal sites, YMD and 242L. The 242 lateral is a conveyance system for discharge water from a series of 21 wells located along and north of the southern United States-Mexico international boundary. The wells pump water from the deep aquifer and are the source of water for the 242L station, which had the most unique chemistry of the sites due to groundwater being the source water (fig. 4).

\begin{tabular}{|c|c|c|c|c|c|c|c|c|c|c|}
\hline $\begin{array}{l}\text { Map } \\
\text { identifier }\end{array}$ & $\begin{array}{l}\text { USGS } \\
\text { station } \\
\text { number }\end{array}$ & Regression model & $\begin{array}{l}\text { Adjusted } \\
\qquad \mathbf{R}^{2}\end{array}$ & $\begin{array}{l}\text { Model } \\
\text { standard } \\
\text { error }\end{array}$ & RMSE & $\mathbf{n}$ & $\begin{array}{l}\text { Range in } \\
\text { measured } \\
\text { values }\end{array}$ & $\begin{array}{l}\text { Mean of } \\
\text { measured } \\
\text { values }\end{array}$ & $\begin{array}{l}\text { Median of } \\
\text { measured } \\
\text { values }\end{array}$ & $\begin{array}{l}\text { Standard } \\
\text { deviation }\end{array}$ \\
\hline 1 & 09429490 & $\begin{array}{c}\mathrm{DS}=-30.8+-1.454 * \\
\mathrm{WT}+0.6796 * \mathrm{SC}\end{array}$ & 0.969 & 1.65 & 5.91 & 36 & $\begin{array}{l}\text { DS 638-780 } \\
\text { SC 1,040-1,240 } \\
\text { WT 11.1-30.9 }\end{array}$ & $\begin{array}{r}690 \\
1,110 \\
20.8\end{array}$ & $\begin{array}{r}680 \\
1,100 \\
20.2\end{array}$ & $\begin{array}{c}33.4 \\
43.2 \\
6.49\end{array}$ \\
\hline 2 & 09522005 & $\begin{array}{l}\mathrm{DS}=87.4+-2.033 * \mathrm{WT} \\
\quad+0.5945 * \mathrm{SC}\end{array}$ & 0.961 & 3.23 & 11.6 & 36 & $\begin{array}{l}\text { DS } 742-991 \\
\text { SC 1,170-1,610 } \\
\text { WT } 13.2-30.80\end{array}$ & $\begin{array}{r}814 \\
1,300 \\
21.1\end{array}$ & $\begin{array}{r}812 \\
1,300 \\
20.8\end{array}$ & $\begin{array}{c}58.3 \\
90.4 \\
5.85\end{array}$ \\
\hline 3 & 09534000 & $\mathrm{DS}=-50.1+0.6581 * \mathrm{SC}$ & 0.976 & 4.36 & 18.9 & 35 & $\begin{array}{l}\text { DS } 946-1,450 \\
\text { SC } 1,520-2,260\end{array}$ & $\begin{array}{l}1,180 \\
1,870\end{array}$ & $\begin{array}{l}1,180 \\
1,920\end{array}$ & $\begin{array}{l}119 \\
179\end{array}$ \\
\hline 4 & 09534550 & $\mathrm{DS}=337+0.4044 * \mathrm{SC}$ & 0.876 & 5.98 & 26.6 & 34 & $\begin{array}{l}\text { DS } 994-1,390 \\
\text { SC } 1,690-2,580\end{array}$ & $\begin{array}{l}1,150 \\
2,000\end{array}$ & $\begin{array}{l}1,140 \\
2,000\end{array}$ & $\begin{array}{l}75.4 \\
178\end{array}$ \\
\hline
\end{tabular}
Specific conductance and dissolved-solids concentrations generally are lowest at the upstream site (CRID) and increase downstream (south) through the Yuma Valley to YMD (fig. 5). Increases were likely a result of irrigation return flows and

Table 4. Regression models and summary statistics for estimating concentrations of dissolved solids in water at four stations in the Yuma, Arizona, area between Imperial Dam and the United States-Mexico southerly international boundary, January 2017 to March 2019.

[USGS, U.S. Geological Survey; DS, dissolved solids in milligrams per liter; WT, water temperature in degrees Celsius; SC, specific conductance, in microsie-

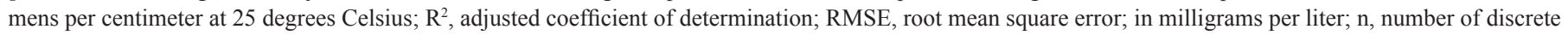
samples] 

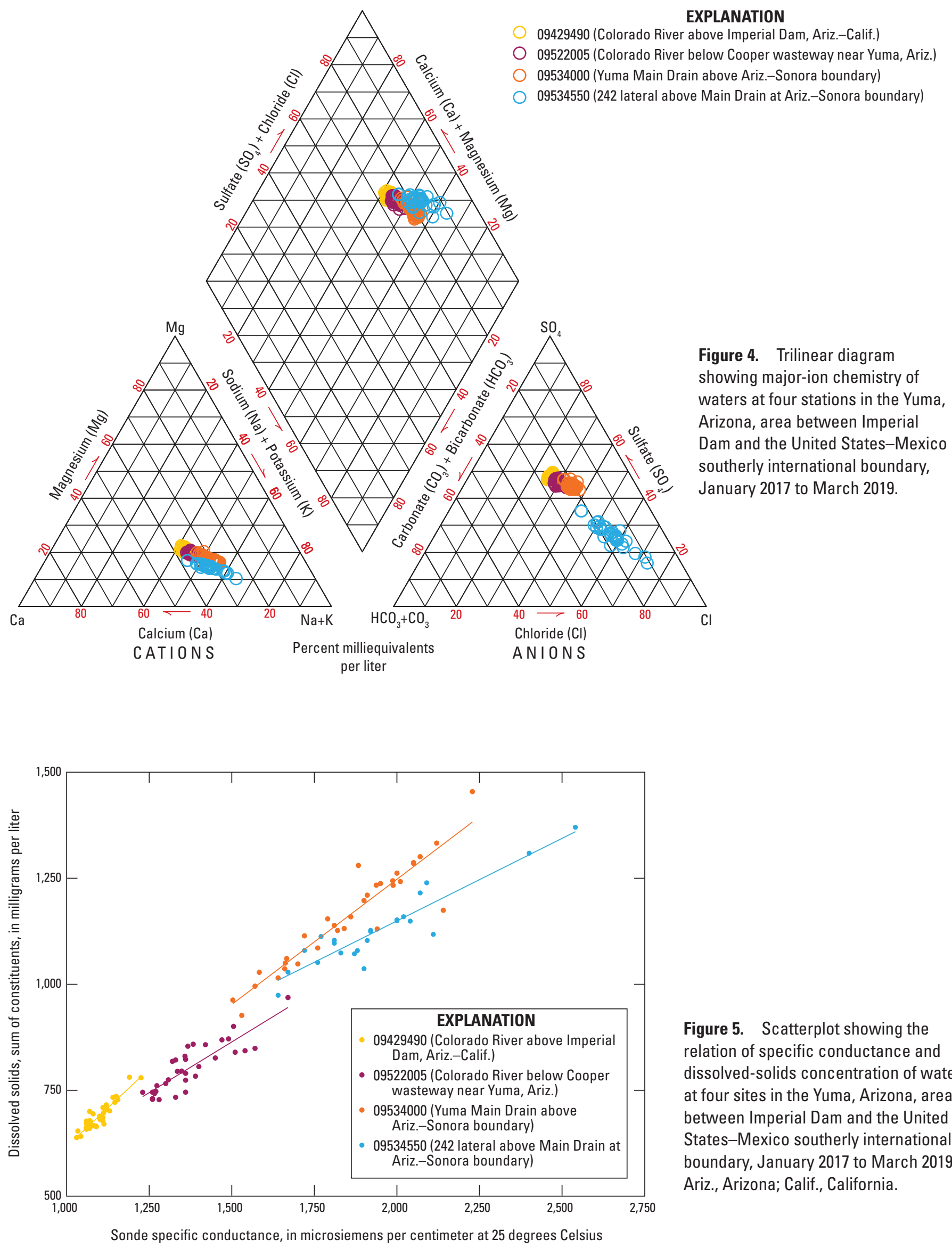

Figure 5. Scatterplot showing the relation of specific conductance and dissolved-solids concentration of waters at four sites in the Yuma, Arizona, area between Imperial Dam and the United States-Mexico southerly international boundary, January 2017 to March 2019. Ariz., Arizona; Calif., California. 
shallow groundwater inflows to the Colorado River downstream from Imperial Dam and to the Yuma Main Drain. The YMD and 242L sites each had constituents that had significantly greater concentrations than CRID and CRCW, although several constituents such as sulfate and chloride were different between YMD and 242L. Although YMD had the greatest variability in dissolved solids (coefficient of variability, 10.2 percent), 8 of the 11 constituents used in the dissolved-solids calculation were most variable at 242L. Mean dissolved-solids concentrations were $690,814,1,150$, and $1,180 \mathrm{mg} / \mathrm{L}$ for CRID, CRCW, 242L, and YMD, respectively (fig. 6). The Colorado River
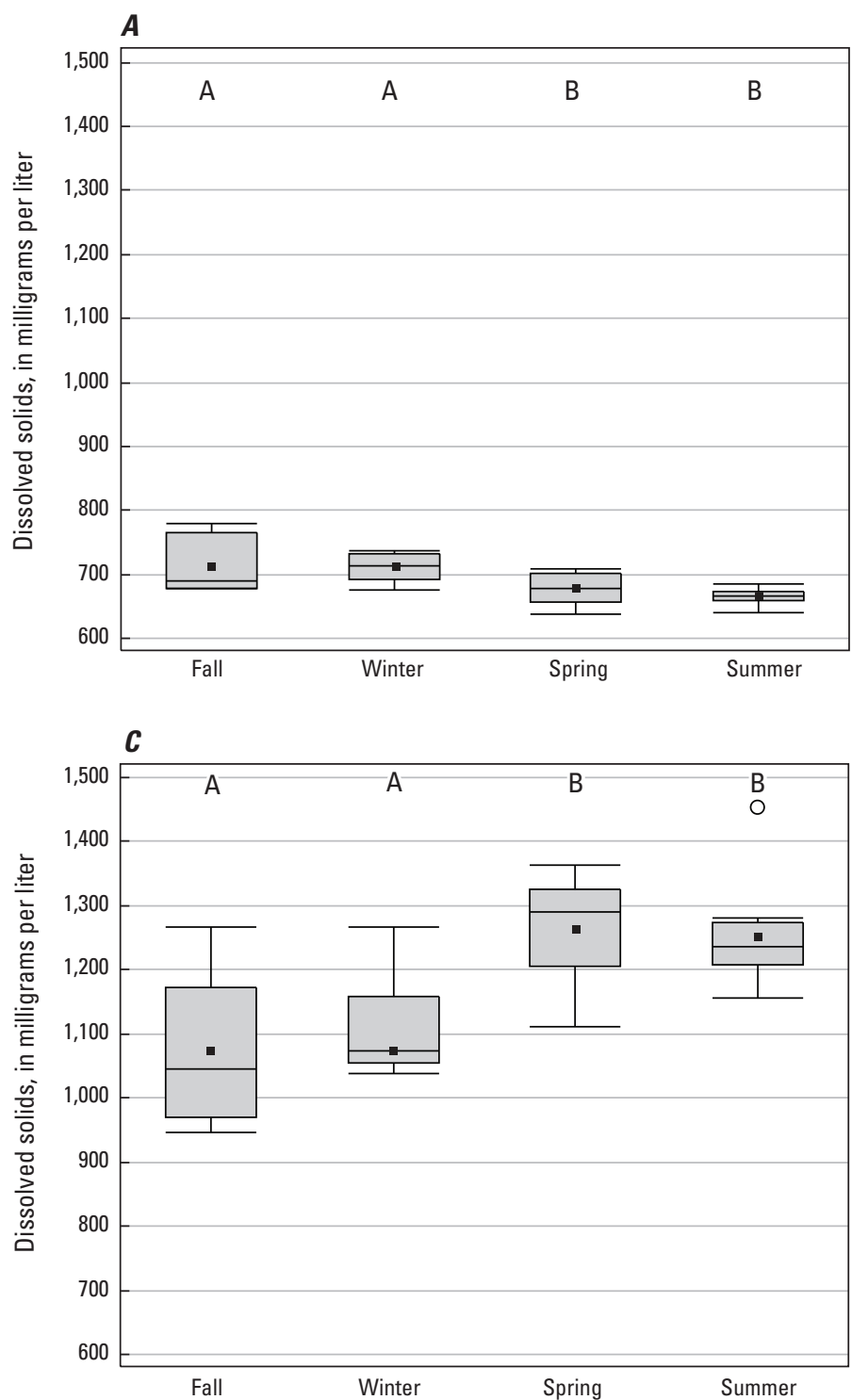

at NIB, just upstream from CRCW, and has very similar concentrations and patterns to $\mathrm{CRCW}$.

Mean dissolved-solid concentrations at the main Colorado River sites, CRID and CRCW, were greater in the fall and winter months compared to spring and summer months (39 and $78 \mathrm{mg} / \mathrm{L}$ difference, respectively; fig. 6A and $6 \mathrm{~B}$. At YMD, the seasonal variability in dissolvedsolid concentrations was the inverse of the main river sites where summer and spring months were greater by $165 \mathrm{mg} / \mathrm{L}$ (fig. 6C). The seasonal effects were least influential at 242L where no significant difference was observed.
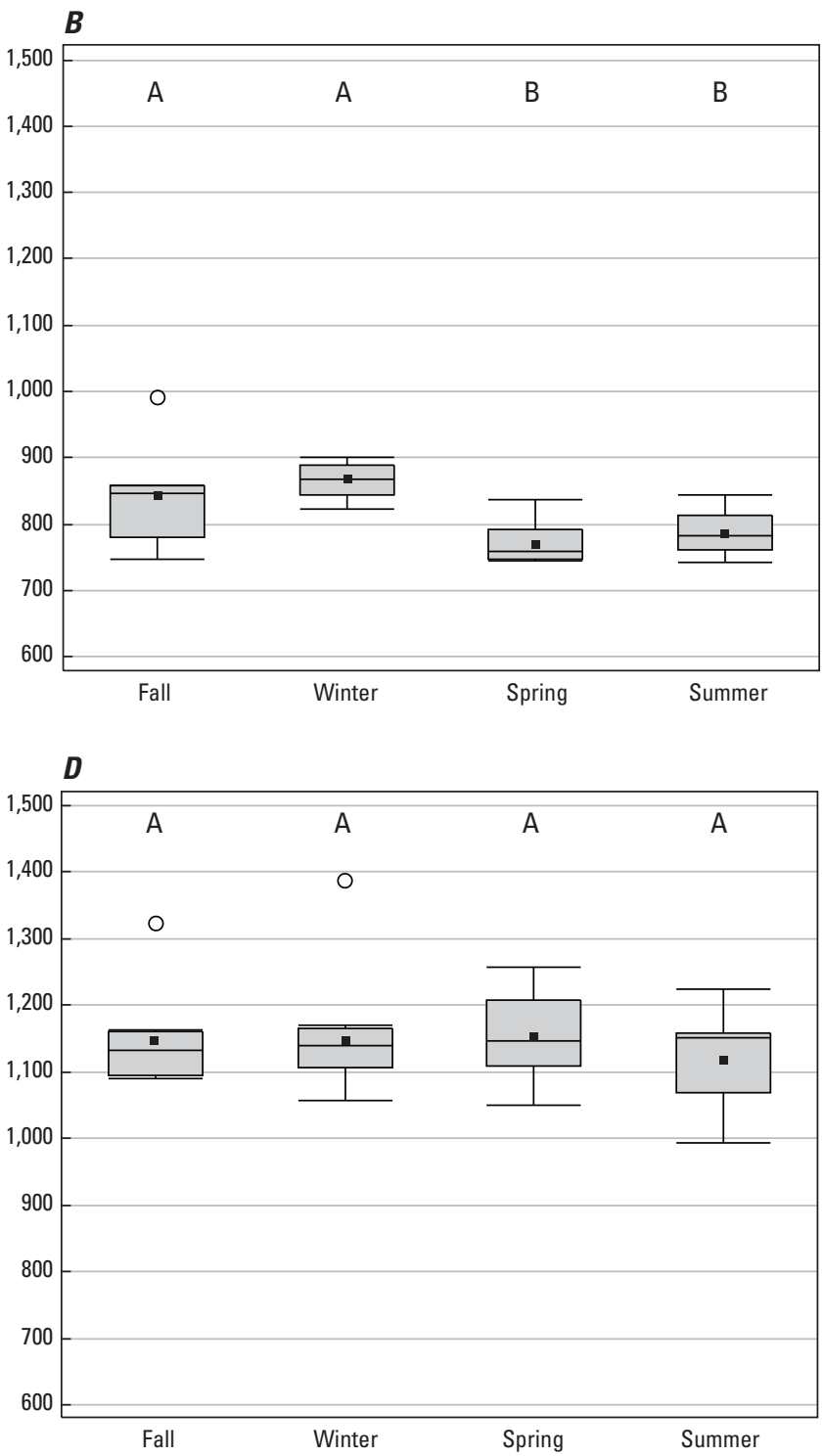

Figure 6. Boxplot diagrams $(A-D)$ comparing dissolved-solids concentrations at four sites in the Yuma, Arizona, area from January 2017 to March 2019. Different letters above boxplots indicate groups that are significantly different; $\mathrm{p} \leq 0.05$ Wilcoxon pairwise comparison. $A, 09429490$ (Colorado River above Imperial Dam); $B, 09522005$ (Colorado River below Cooper wasteway near Yuma, Arizona); C, 09534000 (Yuma Main Drain above Arizona-Sonora boundary), D, 09534550 (242 lateral above Main Drain at Arizona-Sonora boundary).

\section{EXPLANATION}

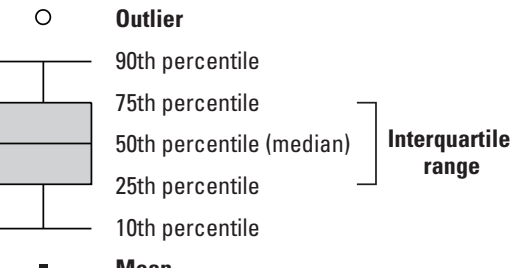




\section{Colorado River above Imperial Dam, Arizona- California}

Most of the streamflow entering the Yuma area, primarily from the Colorado River, is accounted for by water agencies at Imperial Dam. CRID is also an accounting station for waterquality purposes where water chemistry is monitored and used to account for dissolved solids entering into the system. The multiparameter water-quality sonde was mounted in the backwater of the dam and on the north side of the outflow structure for the All American Canal (fig. 2A). Water quality measurements, collected along cross-sectional profiles at the site during discrete sampling, indicated that the site is reasonably well mixed, and the mean value of the measurements is comparable to the value recorded at the sonde during the same time period.

Daily mean streamflow at CRID ranged from 2,290 to 11,700 cubic feet per second change to $\left(\mathrm{ft}^{3} / \mathrm{s}\right)$, and instantaneous specific conductance ranged from 966 to $1,530 \mu \mathrm{S} / \mathrm{cm}$. Streamflow had the largest influence on specific conductance (inversely correlated) and temperature (correlated; fig. 7). Daily variability in specific conductance was generally low (mean coefficient of variation, 1.4 percent) and higher fluctuations were related to fluctuations in streamflow. The regression model developed to estimate dissolved solids used specific conductance and temperature as the primary parameters explaining 96.9 percent (adjusted coefficient of determination; $\mathrm{R}^{2}$ ) of the variability in concentrations. The modeled versus the measured dissolved solids showed close agreement, exemplified by the lowest root mean square error (RMSE) of about $6 \mathrm{mg} / \mathrm{L}$ (table 5) and through a plot of the time series that showed agreement except for four to five samples biased evenly, low or high (fig. 8). Of the two parameters used in the model, specific conductance explained roughly 90 percent of the variability in dissolved solids, and, although temperature only explained about 7 percent of the variability, it also served as a proxy for a seasonal effect. Periodic transformations were also used to represent seasonal variability and were calculated as the cosine and sine of the day of the year. Both were significant; however, together they explained slightly less of the variability than temperature alone. These variables are more difficult parameters to compute and apply to continuous data. For these reasons, temperature was used instead of the two seasonal variables. The dissolved-solids model (table 4) was constructed with specific conductance limits between 1,040 and $1,240 \mu \mathrm{S} / \mathrm{cm}$, which represents about 87 percent of the observed daily mean specific conductance values and 85 percent of the instantaneous specific conductance measured at CRID during the study (fig. 9).

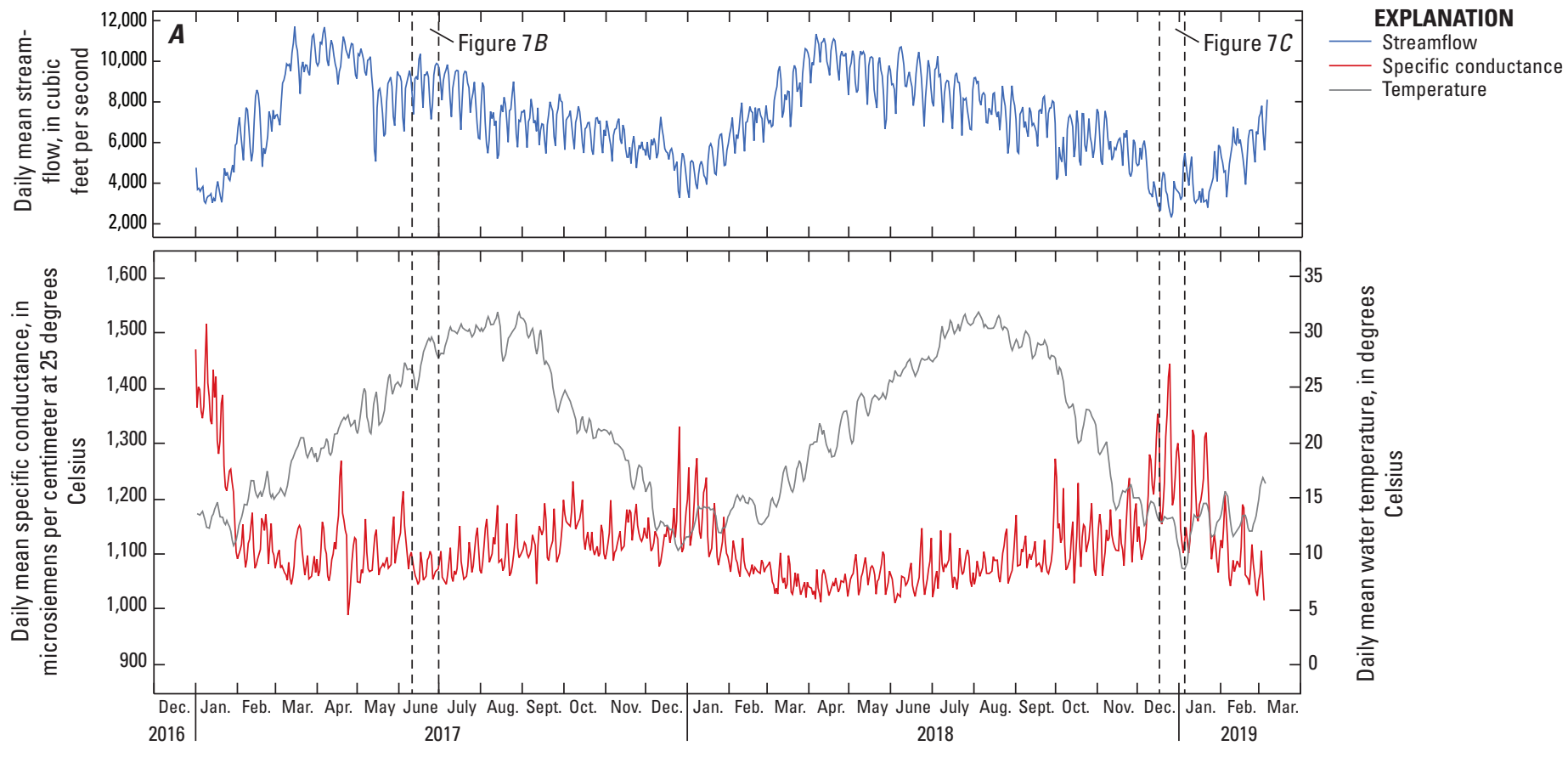

Figure 7 (pages 12-13). Line graphs showing streamflow, specific conductance, and water temperature at station 09429490 (Colorado River above Imperial Dam, Arizona-California) for the period of study from January 2017 to March $2019(A)$ and the daily relation between parameters for June 12, 2017 to July 1, $2017(B)$ and December 16, 2018 to January 3, 2019 (C). 

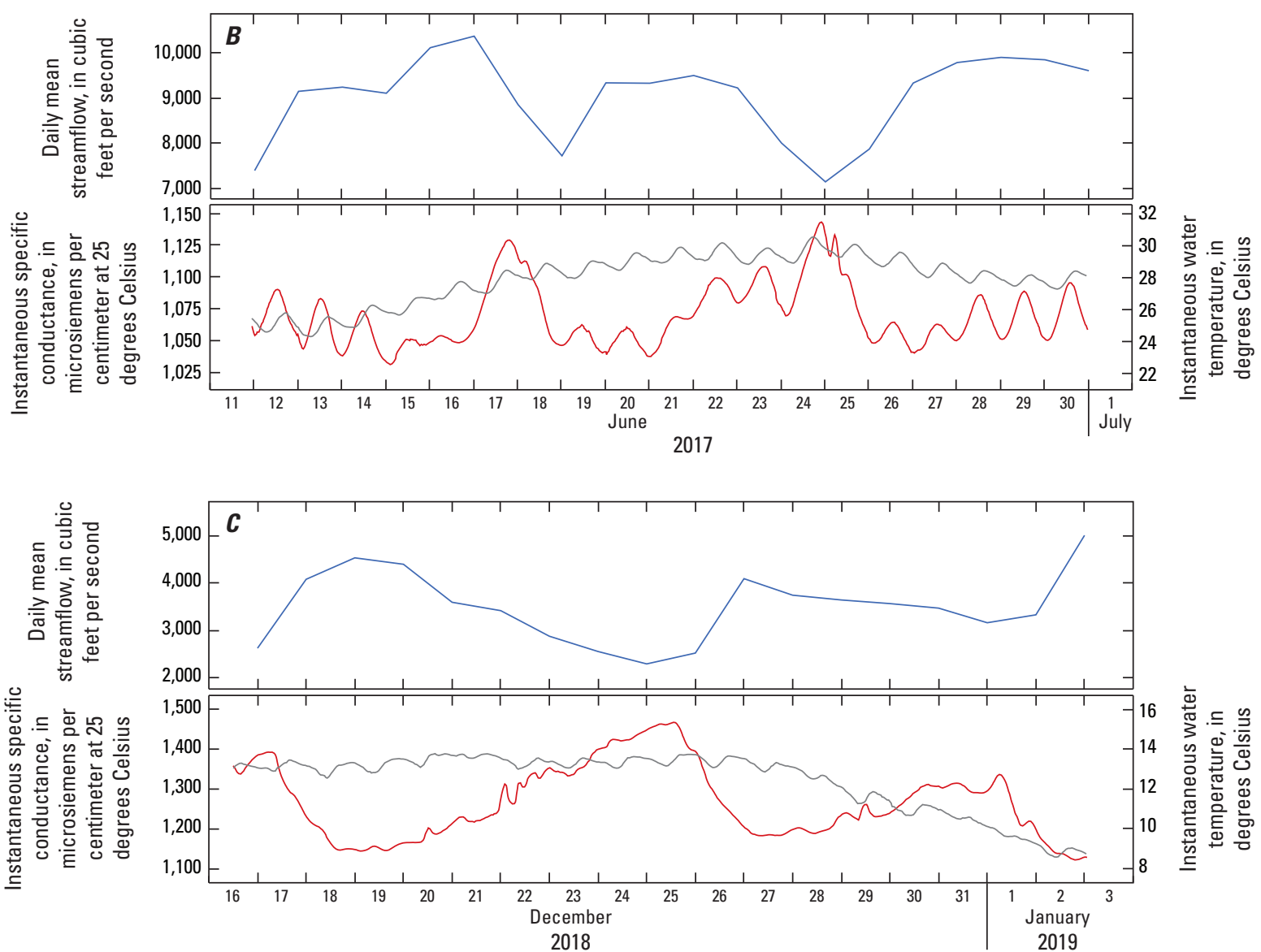

Figure 7 (pages 12-13).-Continued

EXPLANATION

_ Streamflow
Specific conductance

Table 5. Regression model correlation statistics for estimating concentrations of dissolved solids in water at four stations in the Yuma, Arizona, area between Imperial Dam and the United States-Mexico southerly international boundary, January 2017 to March 2019.

[USGS, U.S. Geological Survey; PRESS, predicted residual error sum of squares; RMSE, root mean square error; SC, specific conductance, in microsiemens per centimeter at 25 degrees Celsius; WT, water temperature in degrees Celsius; --, not applicable; <, less than; VIF, variance inflation factor]

\begin{tabular}{cccccccc}
\hline $\begin{array}{c}\text { Map } \\
\text { identifier }\end{array}$ & $\begin{array}{c}\text { USGS } \\
\text { station number }\end{array}$ & Variables & t-ratios & p-value & $\begin{array}{c}\text { Durbin-Watson } \\
\text { (autocorrelation) }\end{array}$ & $\begin{array}{c}\text { PRESS } \\
\text { (RMSE) }\end{array}$ & VIF \\
1 & 09429490 & SC & -9.16 & $<0.0001$ & $1.78(0.052)$ & $1,399(6.23)$ & 1.06 \\
& & WT & 28.5 & $<0.0001$ & -- & -- & 1.06 \\
2 & 09522005 & SC & 27.0 & $<0.0001$ & $2.07(-0.0705)$ & $5,400(12.2)$ & 1.04 \\
& & WT & -5.98 & $<0.0001$ & -- & -- & 1.04 \\
\hline 3 & 09534000 & SC & 36.4 & $<0.0001$ & $1.41(0.282)$ & $12,900(19.2)$ & -- \\
\hline 4 & 09534550 & SC & 15.3 & $<0.0001$ & $1.56(0.215)$ & $24,800(27.0)$ & -- \\
\hline
\end{tabular}




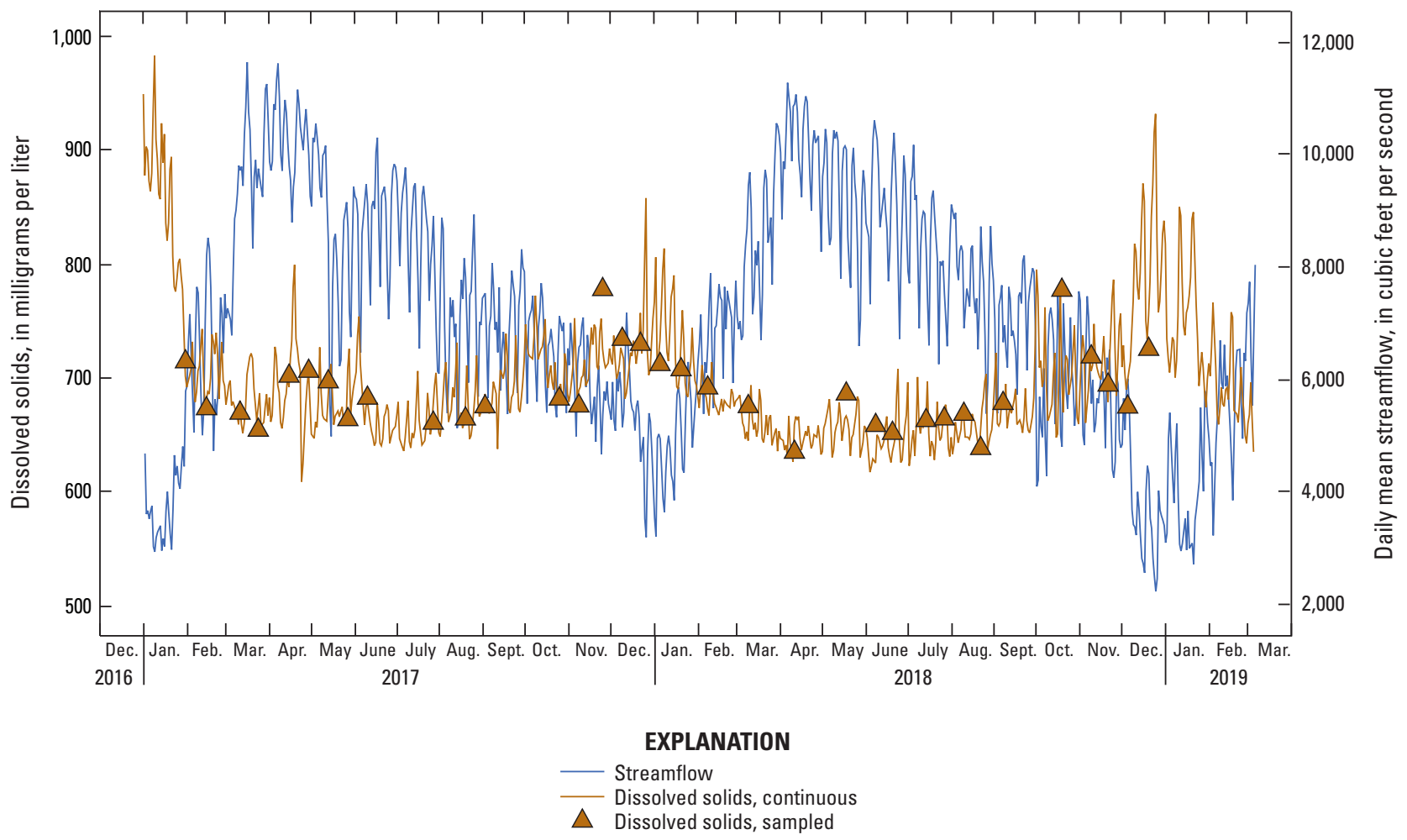

Figure 8. Line graph showing modeled continuous dissolved-solids concentration, sampled dissolved-solids concentration, and streamflow at station 09429490 (Colorado River above Imperial Dam, Arizona-California) from January 2017 to March 2019.

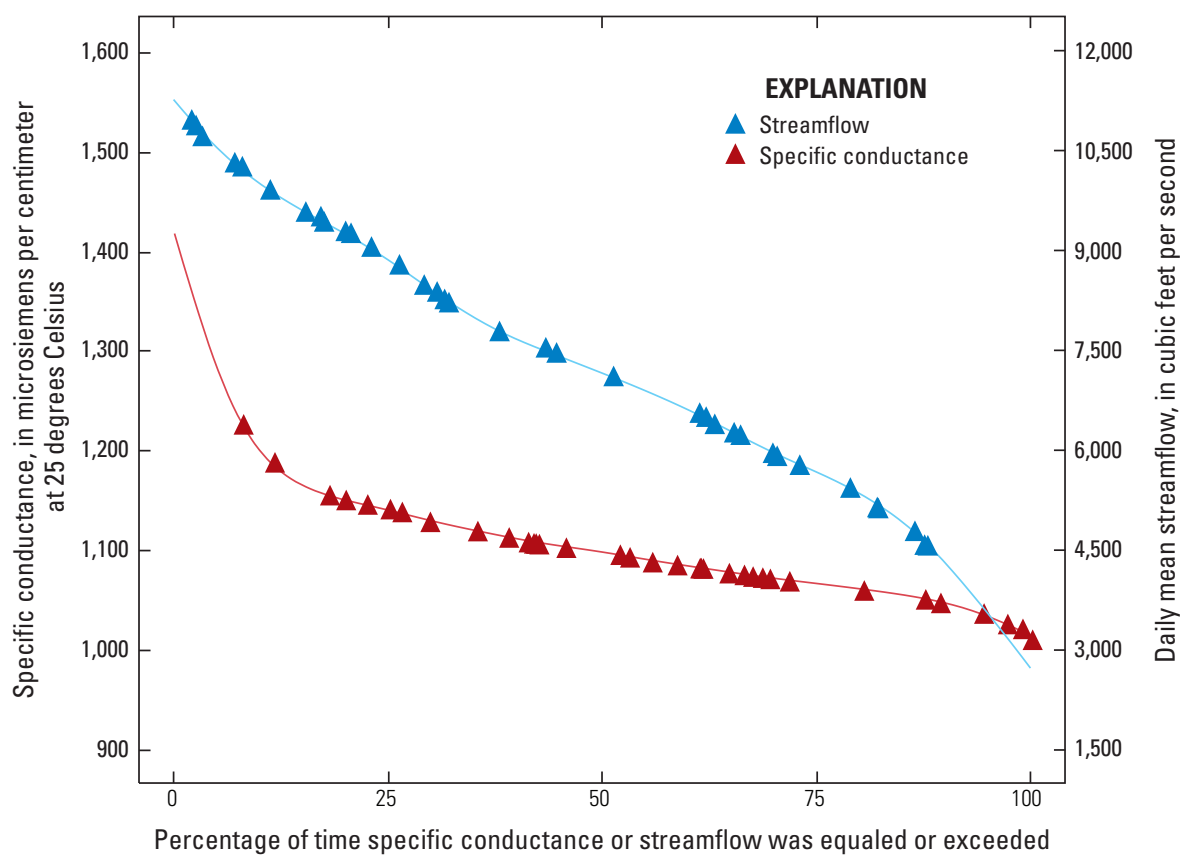

Figure 9. Line graph showing percentage of time specific conductance and streamflow were equaled or exceeded at station 09429490 (Colorado River above Imperial Dam, Arizona-California). 


\section{Colorado River below Cooper Wasteway}

CRCW is approximately 25 miles downstream from CRID, 0.6 mile downstream from NIB, and 0.5 mile upstream from Morelos Dam. The site is located about 0.1 mile downstream from Cooper wasteway, the last wasteway to the Colorado River in the United States before the river is diverted into Mexico through the Alamo Canal at Morelos Dam (fig. 1A). About half a mile upstream from CRCW is the Colorado River at NIB streamgage, which has a long-term dissolved-solids record.

The multiparameter water-quality sonde at $\mathrm{CRCW}$ was mounted in a standpipe located about $10 \mathrm{ft}$ streamward of the east bank of the river (fig. $2 B$ ). Cross-sectional profiles of specific conductance collected at $\mathrm{CRCW}$ indicated this section of the reach is poorly mixed, but the extent of mixing is partially related to streamflow from USGS station 09527000 (Pilot Knob Hydro-electric Plant and Wasteway; hereafter referred to as Pilot Knob). When streamflow from Pilot Knob is low or zero, the east bank monitor has specific conductance values similar to the cross-sectional averaged values.

Increased streamflow from Pilot Knob which discharges on the west bank, can result in a poorly mixed cross section at the site and variations in specific conductance between the west and east bank. Regardless of mixing conditions, the crosssectional specific conductance measurement collected near the east bank is representative of the in-place sensor and is always the highest measurement in the cross section. Differences were apparent in the coefficient of variation, a standardized measure of dispersion, and when streamflow was elevated or increasing at Pilot Knob, the coefficient of variation was greater than 5 percent (fig. 10). Pilot Knob streamflow appeared to be the primary cause of discrepancies between the east and west bank specific conductance. Power generation at Pilot Knob Hydroelectric Plant utilizes water from the All American Canal, which is sourced from Imperial Dam. This water has a similar specific conductance at the generation plant as at the point of diversion, which is lower than the specific conductance in the Colorado River at the Pilot Knob outlet confluence (about 0.4 mile downstream from generation plant). A relation between specific conductance and Pilot Knob streamflow was developed to adjust the east bank monitor values to better represent the mean specific conductance cross section measured during sample collection (fig. 10).

Instantaneous streamflow ranged from 678 to $3,960 \mathrm{ft}^{3} / \mathrm{s}$ at Colorado River at NIB and instantaneous specific conductance ranged from 1,100 to $1,740 \mu \mathrm{S} / \mathrm{cm}$ at $\mathrm{CRCW}$ (fig. 11). Daily variability in specific conductance was lower than CRID (mean coefficient of variation, 0.95 percent). The regression model used specific conductance and water temperature as the primary parameters explaining 96.1 percent of the variability in dissolved-solids concentrations. The modeled versus the measured dissolved solids indicated agreement through a RMSE of about $12 \mathrm{mg} / \mathrm{L}$ although the plot of the time series appears to be biased high for a few samples (fig. 12). Of the two parameters, specific conductance explained roughly 94 percent of the variability in dissolved solids. Water temperature explained less of the variability in the dissolved solids than the model developed for CRID (2.1 percent versus 7 percent). Similar to CRID, water temperature is a proxy for seasonal signal, and without adding this parameter to the model, a periodic function in the model residuals results. The sine of day-of-year was significant, but the cosine was not; the two must be used in concert to properly account for the Fourier transformation. To account for the variability attributable to season when describing dissolved solids, water temperature was determined to be a more efficient and feasible variable to use than was sine and cosine of the day-of-year.

The dissolved-solids model (table 4) was constructed with specific conductance limits between 1,170 and $1,610 \mu \mathrm{S} / \mathrm{cm}$, which represented roughly 94 percent of daily mean specific conductance measured and 95 percent of the observed instantaneous specific conductance (fig. 13). Few samples were collected when specific conductance was greater than $1,400 \mu \mathrm{S} / \mathrm{cm}$.

Two regression models were developed for Colorado River at NIB using samples collected between 1969 and 2019 (sample size of 640) and samples overlapping with the other four sites between 2017 and 2019 (sample size of 40). Specific conductance and water temperature were used in the models to estimate the USGS sum of constituents for dissolved solids. This approach served two purposes: (1) to see if inputs from Cooper wasteway influenced the model and (2) to check or validate the $\mathrm{CRCW}$ model. Regression models for the three datasets were similar in both diagnostic metrics $\left(\mathrm{R}^{2}\right.$ and RMSE) and in dissolved-solids estimation. Adjusted coefficients of determination were between 94 and 96 percent. The RMSE was 28,19 , and $12 \mathrm{mg} / \mathrm{L}$ for the longer record Colorado River at NIB, shorter record Colorado River at NIB, and $\mathrm{CRCW}$ models, respectively. The results indicated the estimation and precision of the estimates is similar between the three models. Results also indicated that potential influences from Cooper wasteway likely did not measurably influence the dissolved-solids model prediction or precision. 


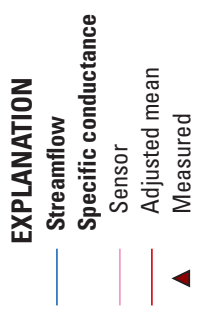

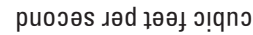
u! 'м0|јшеәдыs иеәш К!e
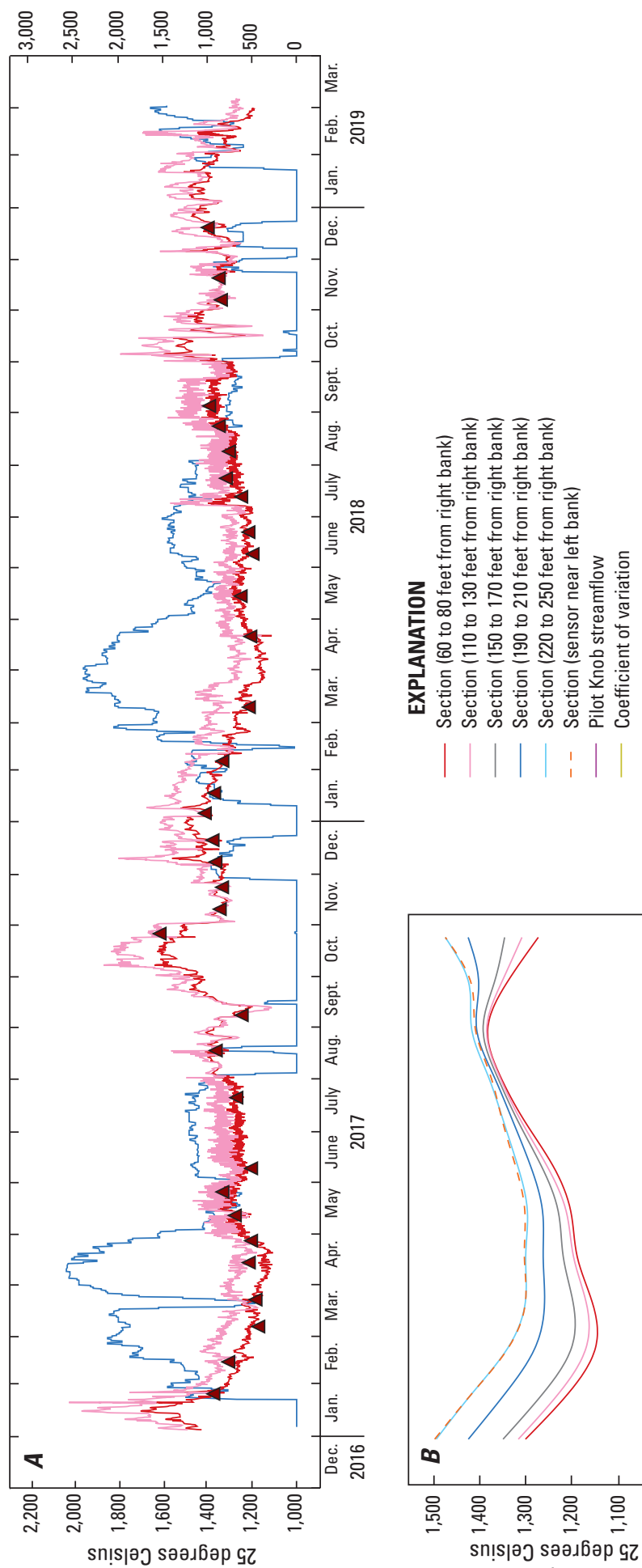

일 要

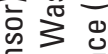

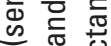

范

중

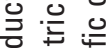

¿ $\frac{\omega}{0}$

은

능 흔

흐오동

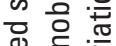

更

空 음

든

i. 迸

잉

는 훙

उ

要

论

焉

के 응

드응 웅

๕ 흔드

흥 SO

无

ن를

puоэәs ıәd ґәәц э!qnว

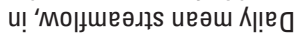

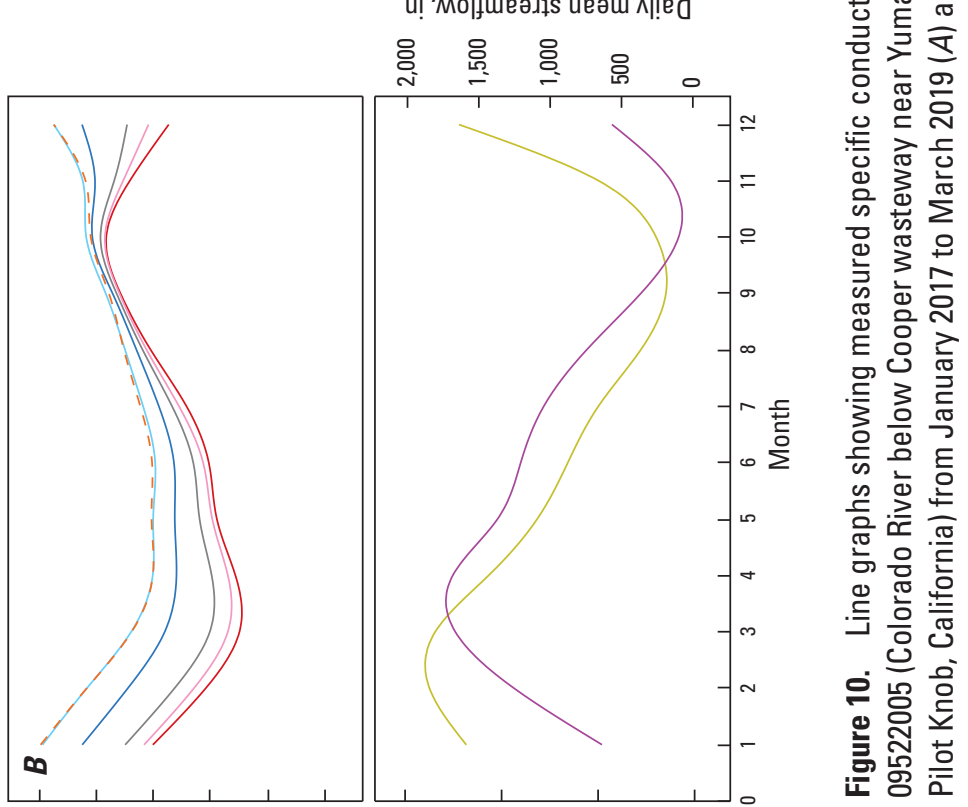

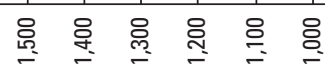

sn!s|әว sәวлбәр c乙

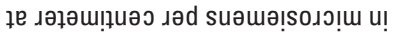

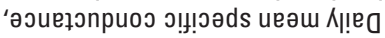

ұนวงภəd u!

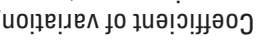



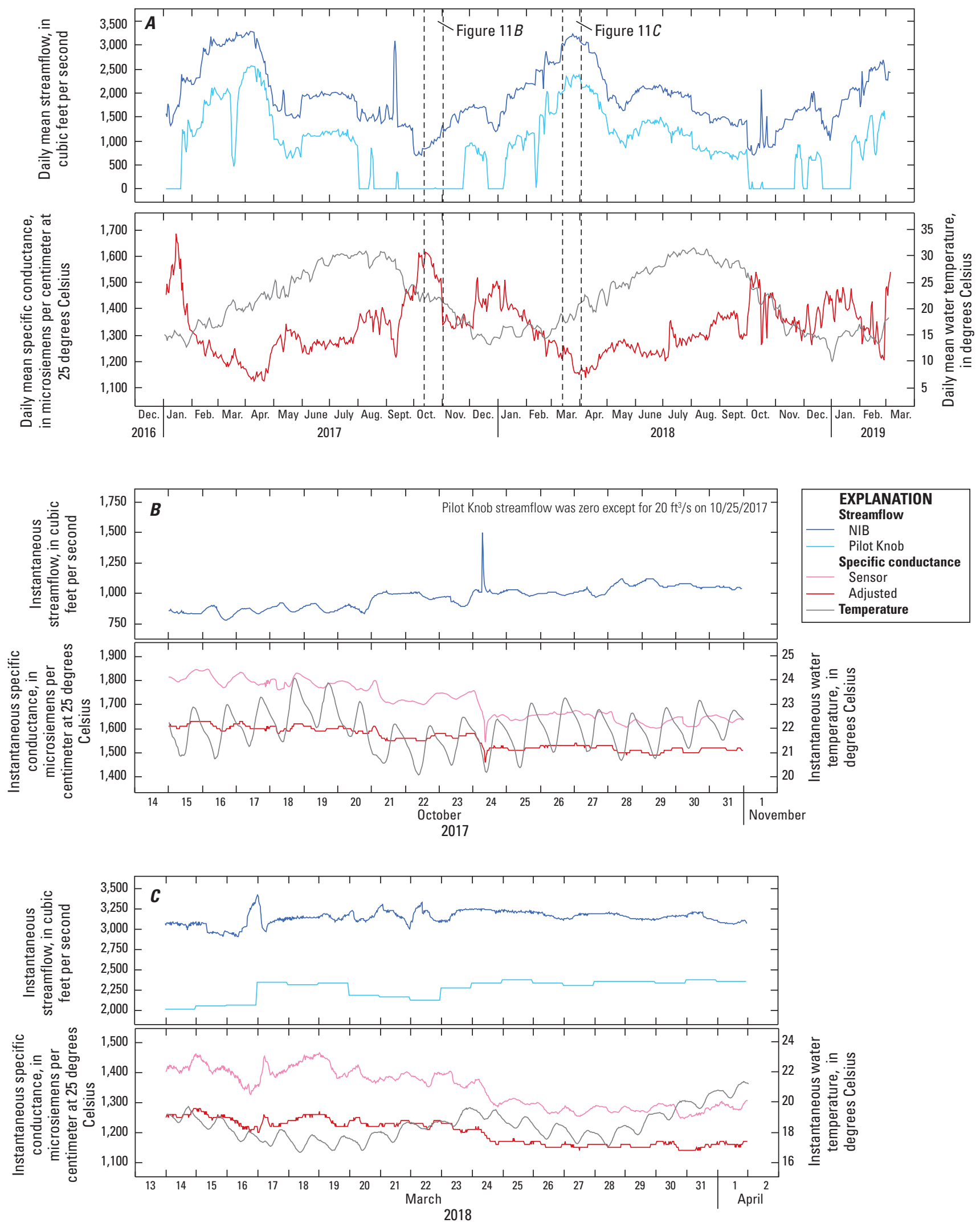

Figure 11. Line graphs showing specific conductance and water temperature at station number 09522005 (Colorado River below Cooper wasteway near Yuma, Arizona) compared to streamflow at 09527000 (Pilot Knob Hydro-electric Plant and Wasteway near Pilot Knob, California) and 09522000 (Colorado River at northerly international boundary [NIB], above Morelos Dam, Arizona) for the period of study from January 2017 to March 2019 (A), from October 15, to November 1, 2017, showing daily relation between parameters during low-flow period $(B)$, and March 14, 2018, to April 2, 2019, showing daily relation between parameters during a high-flow period (C). Streamflow for 09527000 (Pilot Knob) in $11 B$ was zero for all but 0 ctober 25, 2017, when it was 20 cubic feet per second (ft3/s). 


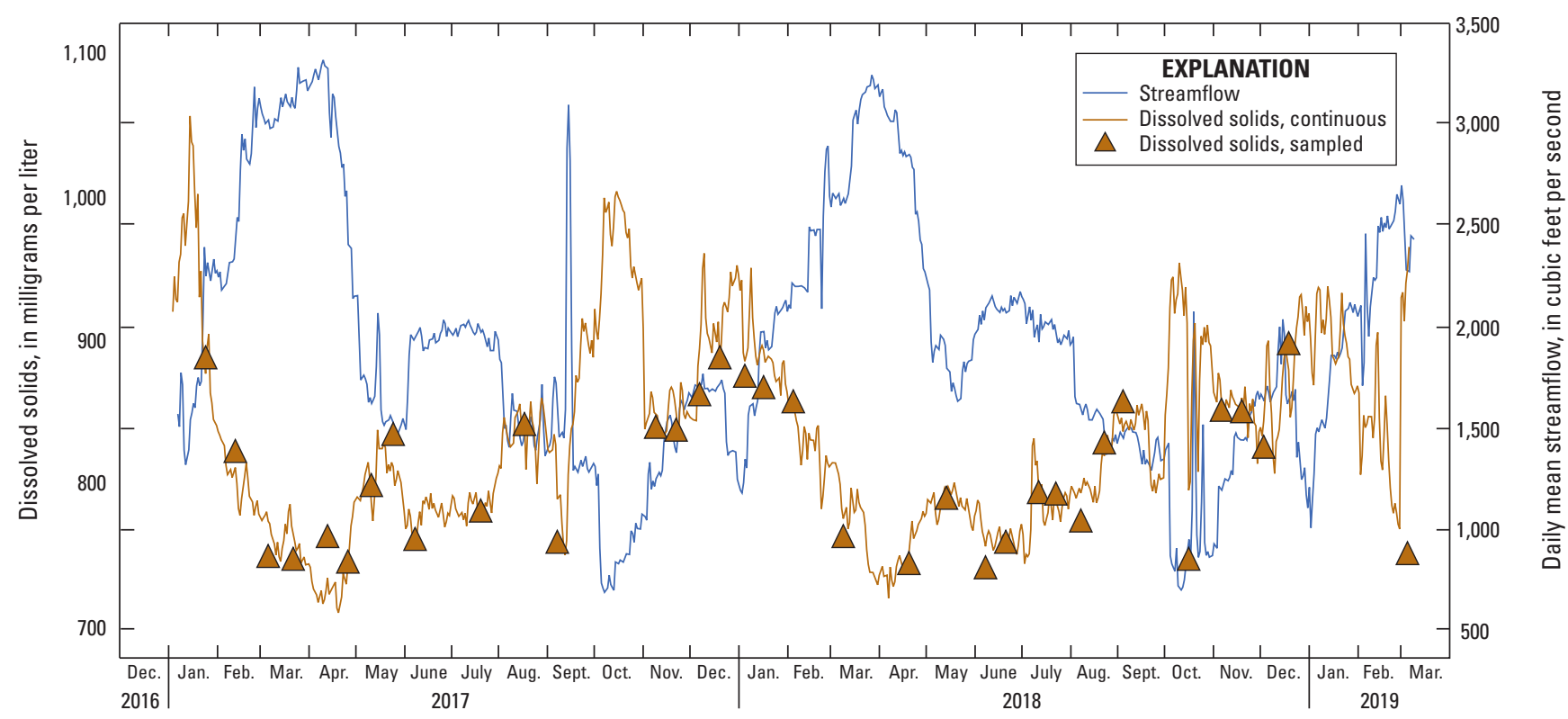

Figure 12. Line graph showing modeled continuous dissolved-solids concentration and sampled dissolved-solids concentration at station 09522005 (Colorado River below Cooper wasteway near Yuma, Arizona) and streamflow at station 09522000 (Colorado River at NIB, above Morelos Dam, Arizona) from January 2017 to March 2019.

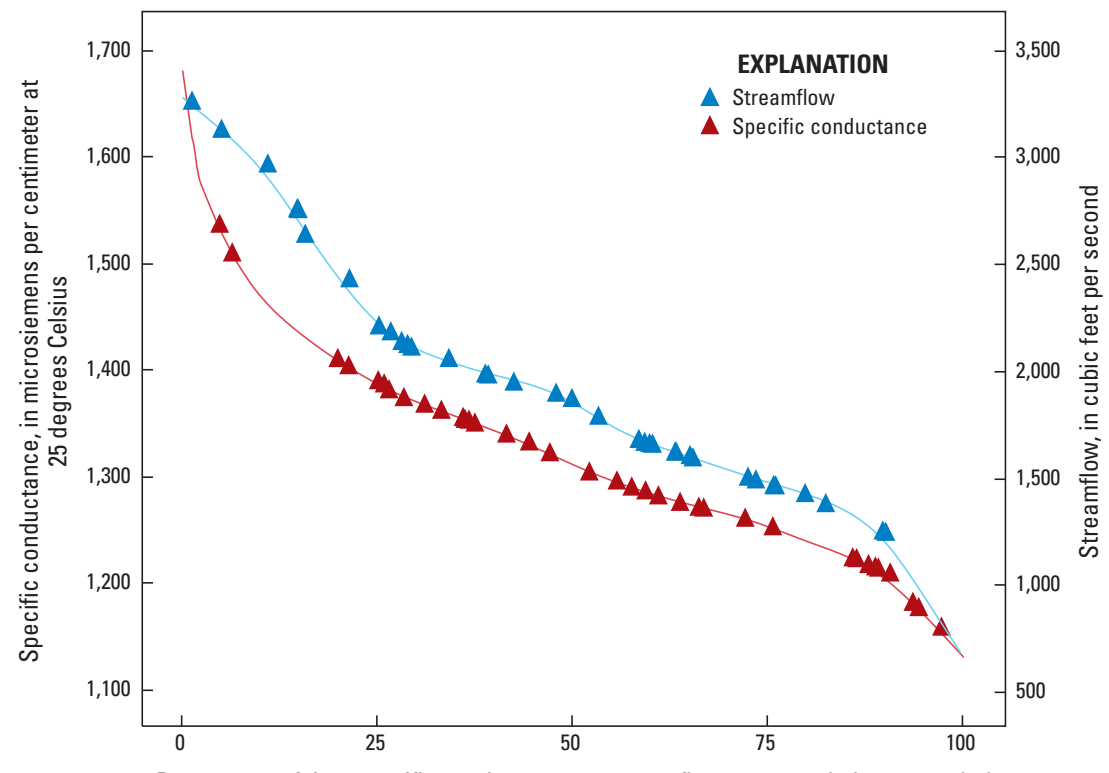

Figure 13. Line graph showing percentage of time specific conductance was equaled or exceeded at station 09522005 (Colorado River below Cooper wasteway near Yuma, Arizona) and streamflow was equaled or exceeded at station 09522000 (Colorado River at northerly international boundary, above Morelos Dam, Arizona).

\section{Yuma Main Drain above Arizona-Sonora Boundary}

The Yuma Main Drain collects discharge from the shallow groundwater system to maintain lower groundwater levels and collects wasteway water from excess water conveyed in the canal system in the Yuma Valley. Specific conductance and dissolved-solids concentrations were elevated in the drain as a result of irrigation return flows and groundwater discharge. The multiparameter water-quality sonde was located on a steel pedestrian bridge downstream from the pump discharge tubes and upstream from the inflow from the 242 lateral (fig. 2C). Cross-sectional profiles of specific conductance collected at the site during discrete sampling indicated that the site was reasonably well mixed, and the mean value of the measurements correlated to the 
value recorded at the sonde during the same time period. Water conveyed in the Yuma Main Drain along with water from the 242 lateral is delivered to Mexico and can account for about 10 percent $(140,000$ acre-ft) of all water delivered to Mexico as part of the Minute 242 agreement.

Instantaneous streamflow ranged from 0 to $233 \mathrm{ft}^{3} / \mathrm{s}$ and instantaneous specific conductance ranged from 1,080 to $2,380 \mu \mathrm{S} / \mathrm{cm}$. The daily mean specific conductance ranged from 1,290 to $2,240 \mu \mathrm{S} / \mathrm{cm}$ (fig. 14). Daily variability in specific conductance was the highest of all the sites (mean coefficient of variation, 3.6 percent). The daily range in specific conductance values had a mean value of $246 \mu \mathrm{S} / \mathrm{cm}$ and daily ranges reaching as much as $660 \mu \mathrm{S} / \mathrm{cm}$. Multiple daily streamflow pulses with ranges upwards of $220 \mathrm{ft}^{3} / \mathrm{s}$ resulted in variable specific conductance. The regression model developed to estimate dissolved solids used specific conductance as the only parameter explaining 97.6 percent of the variability in concentrations. Streamflow at this site was related to the variability in dissolved solids, but as an explanatory variable in the regression it only explained an additional 1 percent of the variability. The model had an RMSE of about $19 \mathrm{mg} / \mathrm{L}$ and visually fit the majority of the observed data with the exception of 3 samples biased high and 2 biased low (fig. 15). The dissolved-solids model was constructed with specific conductance limits between 1,520 and $2,260 \mu \mathrm{S} / \mathrm{cm}$, which represented 92 percent of the daily mean specific conductance and about 93 percent of the observed instantaneous specific conductance (fig. 16).

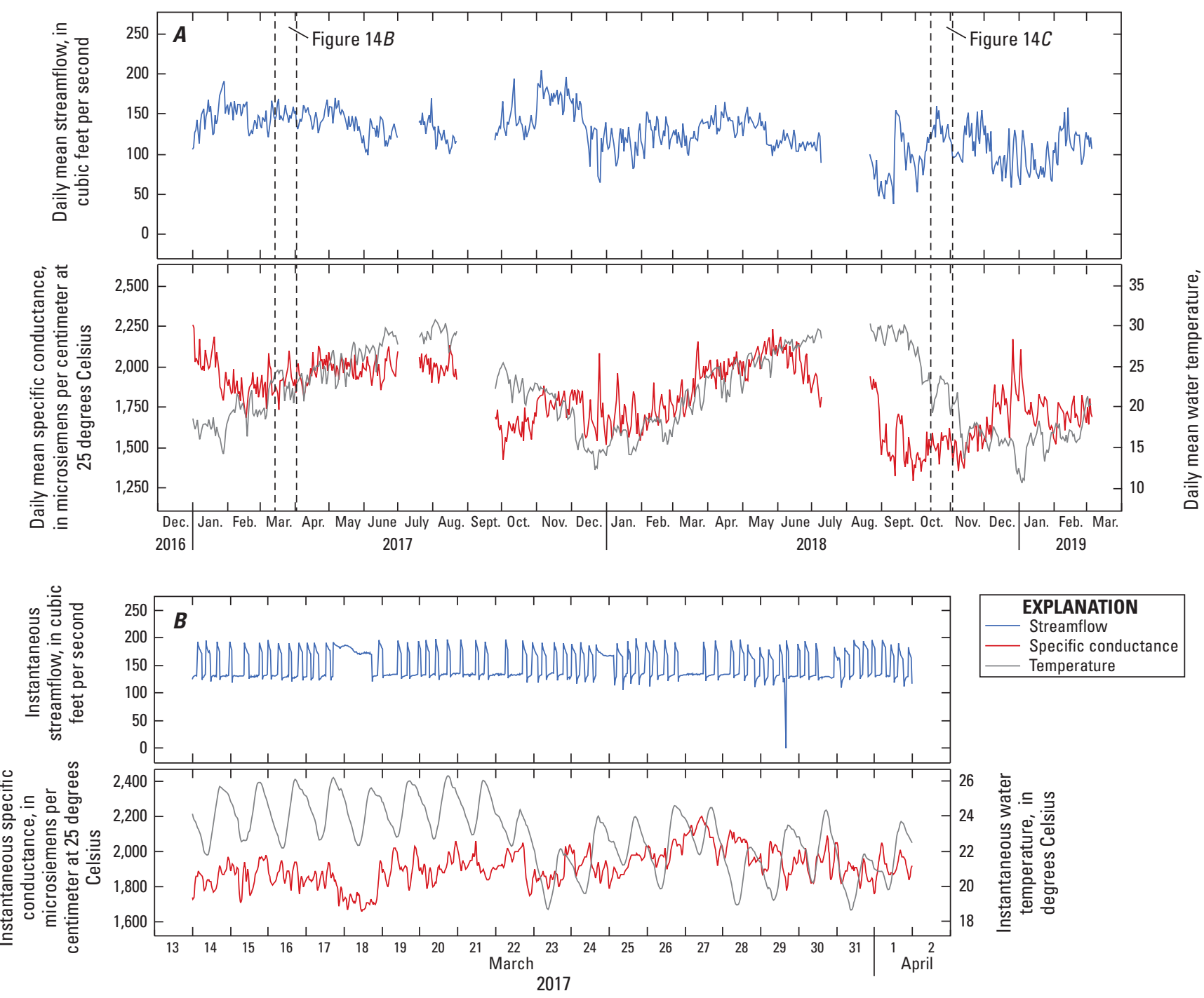

Figure 14 (pages 19-20). Line graphs showing streamflow, specific conductance, and water temperature at station 09534000 (Yuma Main Drain above Arizona-Sonora boundary) for the period of study from January 2017 to March $2019(A)$ and from March 14 to April 3, $2017(B)$, and line graphs of daily relation between parameters from October 15 to November 3, $2018(C)$. Breaks in lines shown in $14 \mathrm{~A}$ represent time periods when erroneous data were collected and not published. 


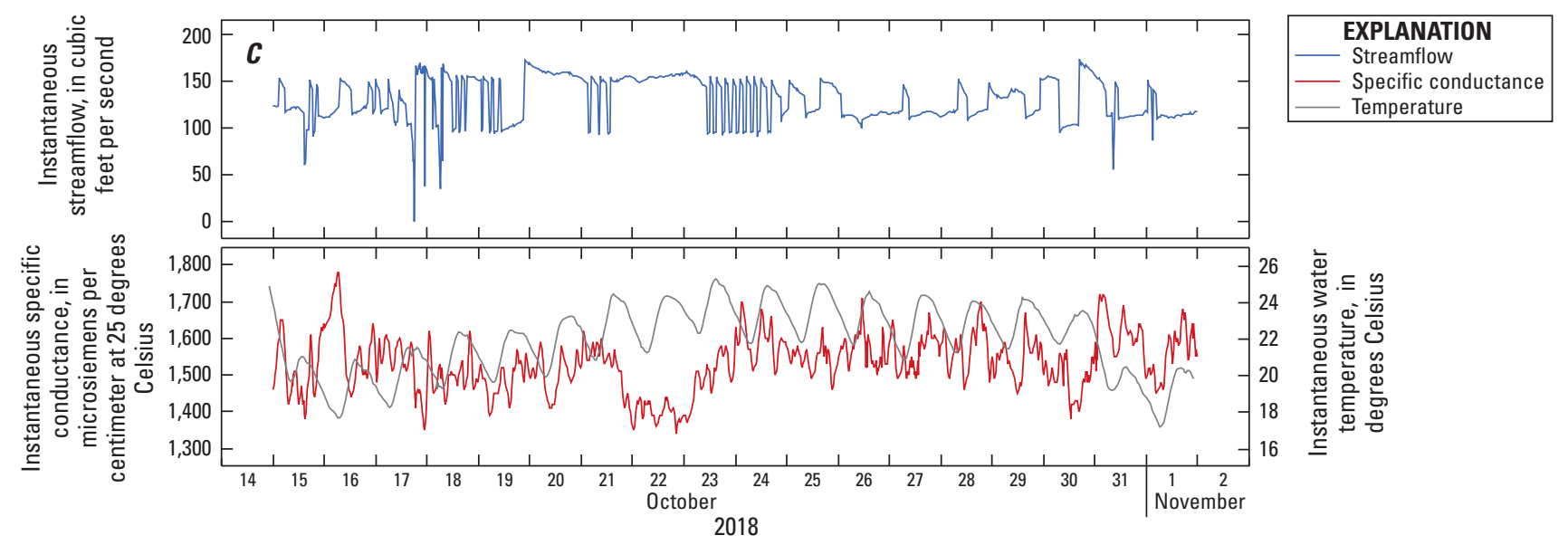

Figure 14 (pages 19-20).-Continued

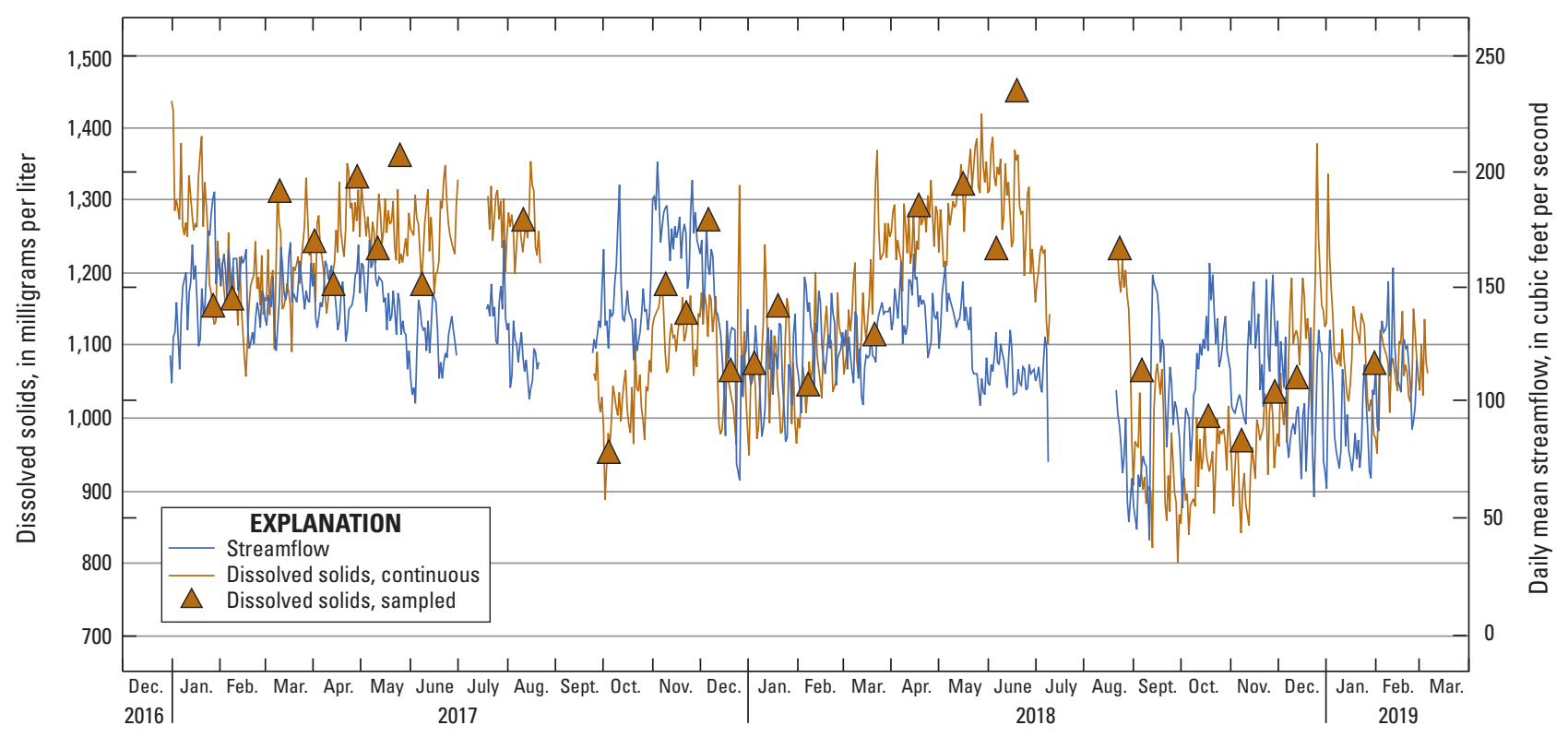

Figure 15. Line graph showing modeled continuous dissolved-solids concentration, sampled dissolved-solids concentration, and streamflow at station 09534000 (Yuma Main Drain above Arizona-Sonora boundary). Breaks in lines represent time periods when erroneous data were collected and not published. 


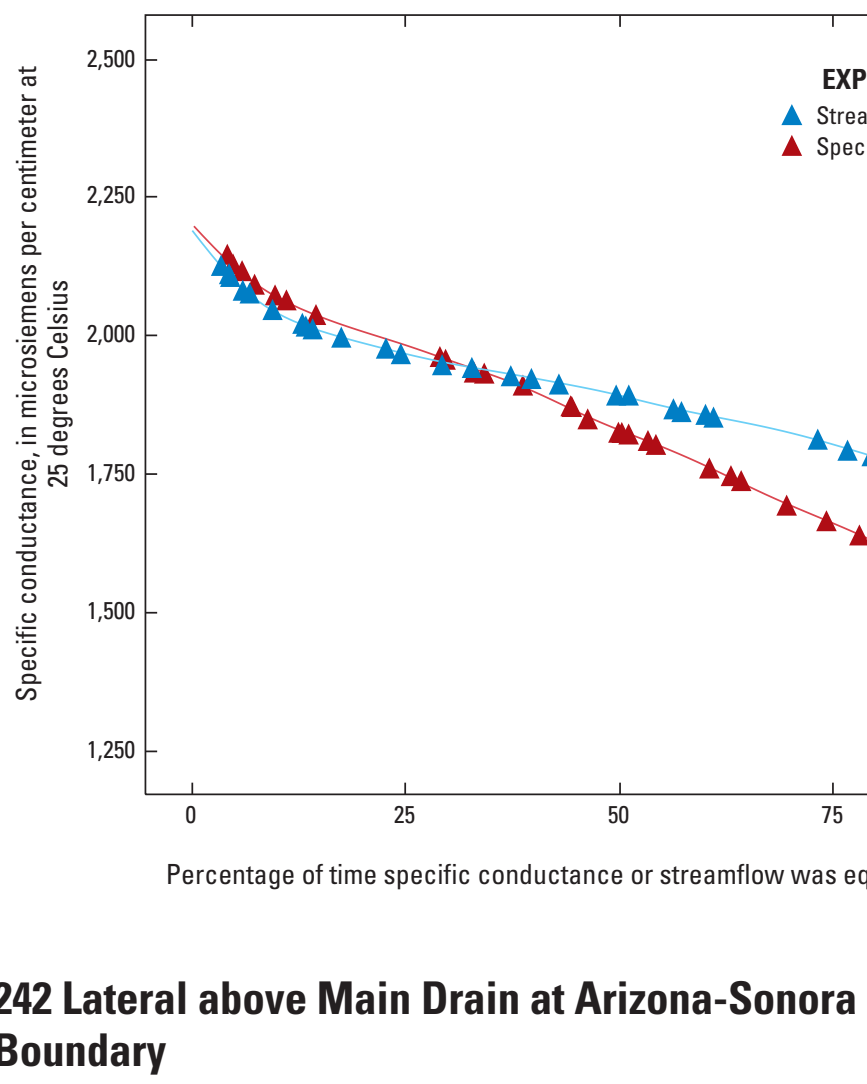

The 242 lateral conveys water pumped from a series of 21 groundwater wells in the 242 well field located north of and adjacent to the SIB on the east side of Yuma Valley. Water conveyed within the 242 lateral flows into the Yuma Main Drain channel about $400 \mathrm{ft}$ downstream from the Yuma Main Drain pump outlet tubes and is delivered to Mexico. The multi-parameter water-quality sonde in the 242 lateral was located on a steel pedestrian bridge about $125 \mathrm{ft}$ upstream from the IBWC 242 lateral streamflow-gage weir. The weir is located about $1,000 \mathrm{ft}$ upstream from the 242 lateral confluence with the Yuma Main Drain (fig. 2D). Cross-sectional profiles of specific conductance collected at the site during discrete sampling indicated that the site was reasonably well mixed and the mean value of the measurements correlated to the value recorded at the sonde during the same time period. Rapidly changing conditions at the site, resulting from changes in groundwater pumping operations, tended to foul the specific conductance sensor. The fouling resulted in erroneous data and poor data quality during some periods. Continued operation at this site would require more frequent site visits for cleaning and service to ensure data quality.
Figure 16. Line graph showing percentage of time specific conductance and streamflow were equaled or exceeded at station 09534000 (Yuma Main Drain above ArizonaSonora boundary).
Instantaneous streamflow ranged from 0 to $144 \mathrm{ft}^{3} / \mathrm{s}$ and daily mean streamflow ranged from 0 to $78.8 \mathrm{ft}^{3} / \mathrm{s}$ (fig. 17). Instantaneous specific conductance ranged from 1,430 to $3,030 \mu \mathrm{S} / \mathrm{cm}$ and daily mean specific conductance ranged from 1,630 to $2,850 \mu \mathrm{S} / \mathrm{cm}$ (fig. $17 A$ ). Daily variability or mean coefficient of variation of specific conductance was higher than the main Colorado River sites but lower than YMD at 2.3 percent, but the time series of specific conductance showed many days with the highest variability of all the sites, coefficient of variation of 22 percent and daily ranges of up to $1,000 \mu \mathrm{S} / \mathrm{cm}$. This likely contributes to the lowest precision of all the models developed. The regression model developed to estimate dissolved solids used specific conductance as the only parameter explaining 87.6 percent of the variability in concentrations $\left(\mathrm{R}^{2}\right)$. The modeled versus the measured dissolved solids had an RMSE of around $27 \mathrm{mg} / \mathrm{L}$. Visually, the plot of the time series showed good agreement with the exception of a few samples biased high (fig. 18). The dissolved-solids model was constructed with specific conductance limits between 1,690 and 2,580 $\mu \mathrm{S} / \mathrm{cm}$, which represented about 97 percent of the daily mean specific conductance values and 92 percent of the observed instantaneous specific conductance (fig. 19). Few samples were collected when specific conductance was above $2,500 \mu \mathrm{S} / \mathrm{cm}$ or streamflow was below $20 \mathrm{ft}^{3} / \mathrm{s}$. 

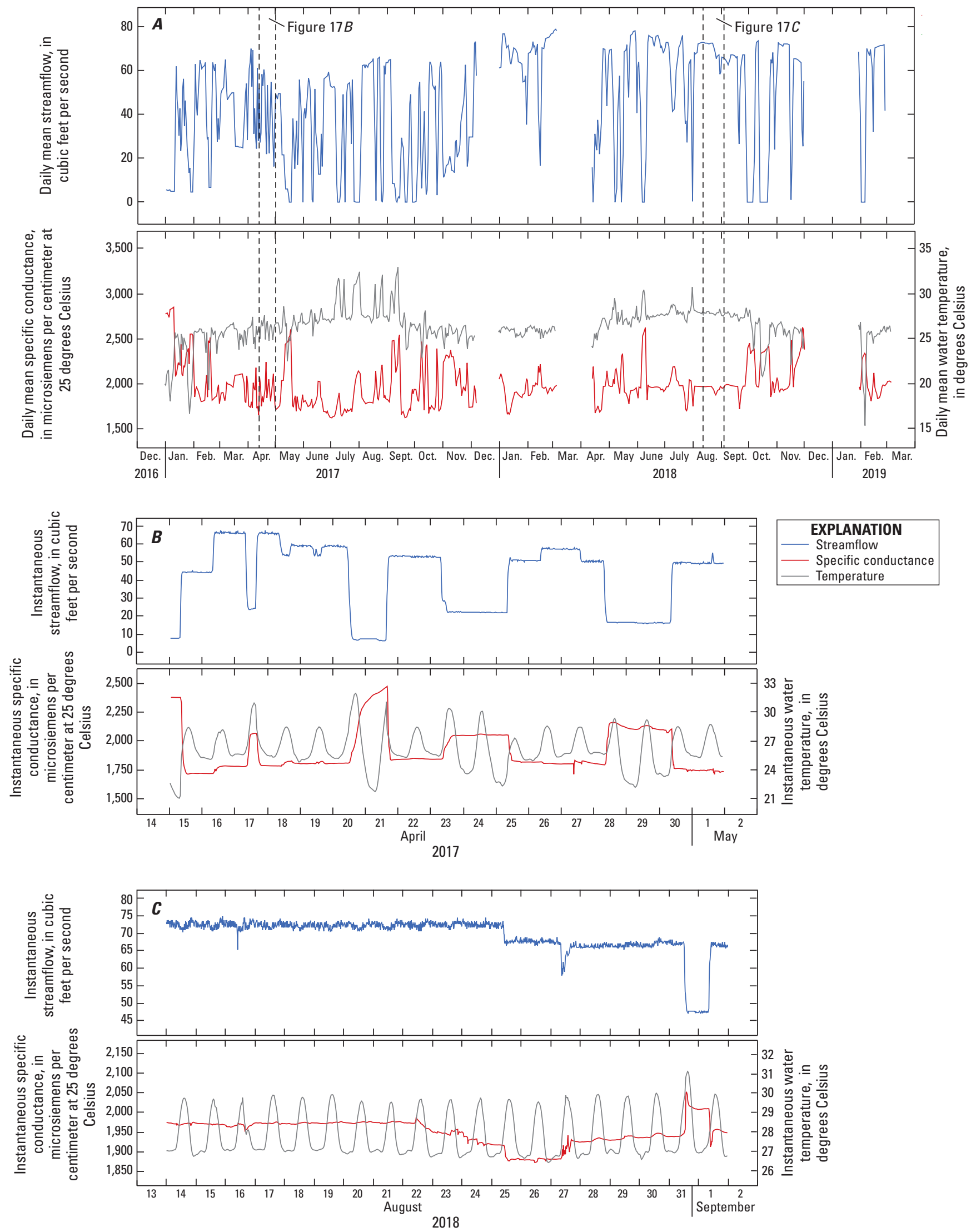

Figure 17. Line graphs showing streamflow, specific conductance, and water temperature at station 09534550 (242 lateral above Main Drain at Arizona-Sonora boundary) for the period of study from January 2017 to March $2019(A)$, and from April 14 to May 3, $2017(B)$ and August 14 to September 2, $2018(C)$ showing daily relation between parameters. Breaks in lines shown in $17 \mathrm{~A}$ represent time periods when erroneous data were collected and not published. 


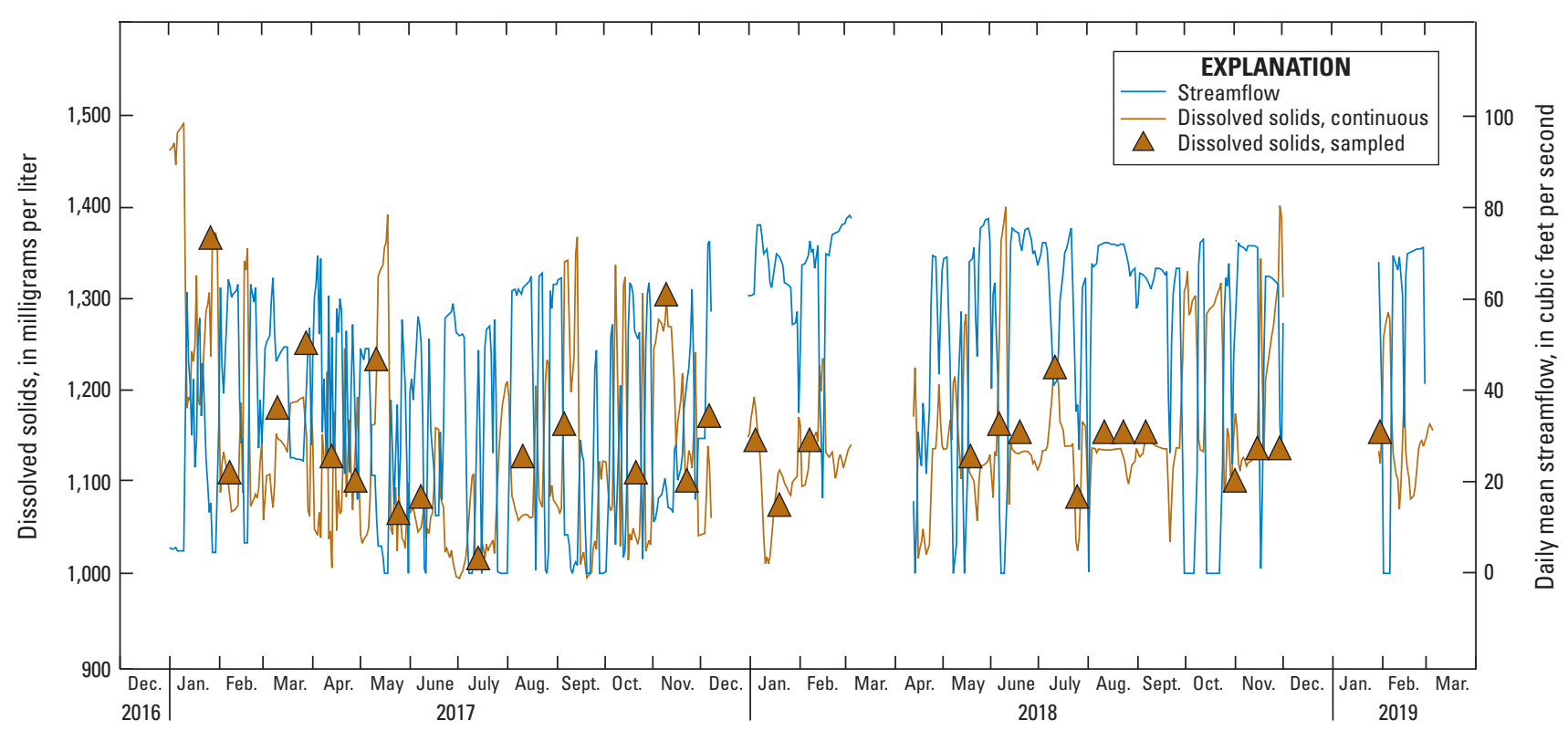

Figure 18. Line graph showing modeled continuous dissolved-solids concentration, sampled dissolved-solids concentration, and streamflow at station 09534550 (242 lateral above Main Drain at Arizona-Sonora boundary). Breaks in lines represent time periods when erroneous data were collected and not published.

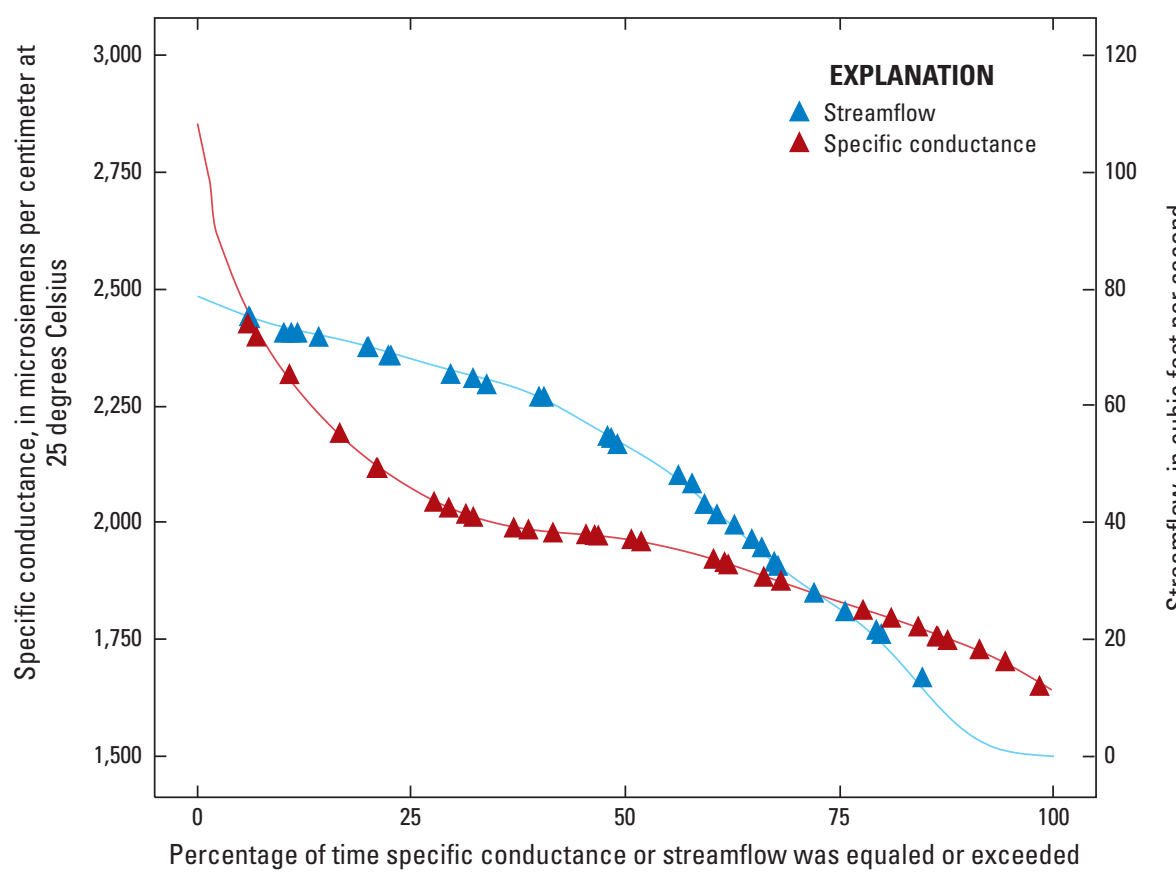

Figure 19. Line graph showing percentage of time specific conductance and streamflow were equaled or exceeded at station 09534550 (242 lateral above Main Drain at ArizonaSonora boundary).

\section{Regression Summary}

The regression models, which were developed using easily measured environment variables (specific conductance and water temperature) to estimate dissolved-solids concentrations at four monitoring sites, had relatively high precision and accuracy as measured by the $\mathrm{R}^{2}$ and RMSE, respectively. The $\mathrm{R}^{2}$ is a statistical measure of how close the data are to the fitted regression line and describes the percentage of the response-variable variation that is explained by a linear model. The RMSE is a measure of how accurately the model predicts the response and has the useful property of being in the same units as the response variable. Lower values of RMSE indicate a better fit. $\mathrm{R}^{2}$ values were highest for CRID and lowest for 242L, which was also reflected in the highest RMSE at 242L and lowest at CRID (table 5) (fig. 20). The 

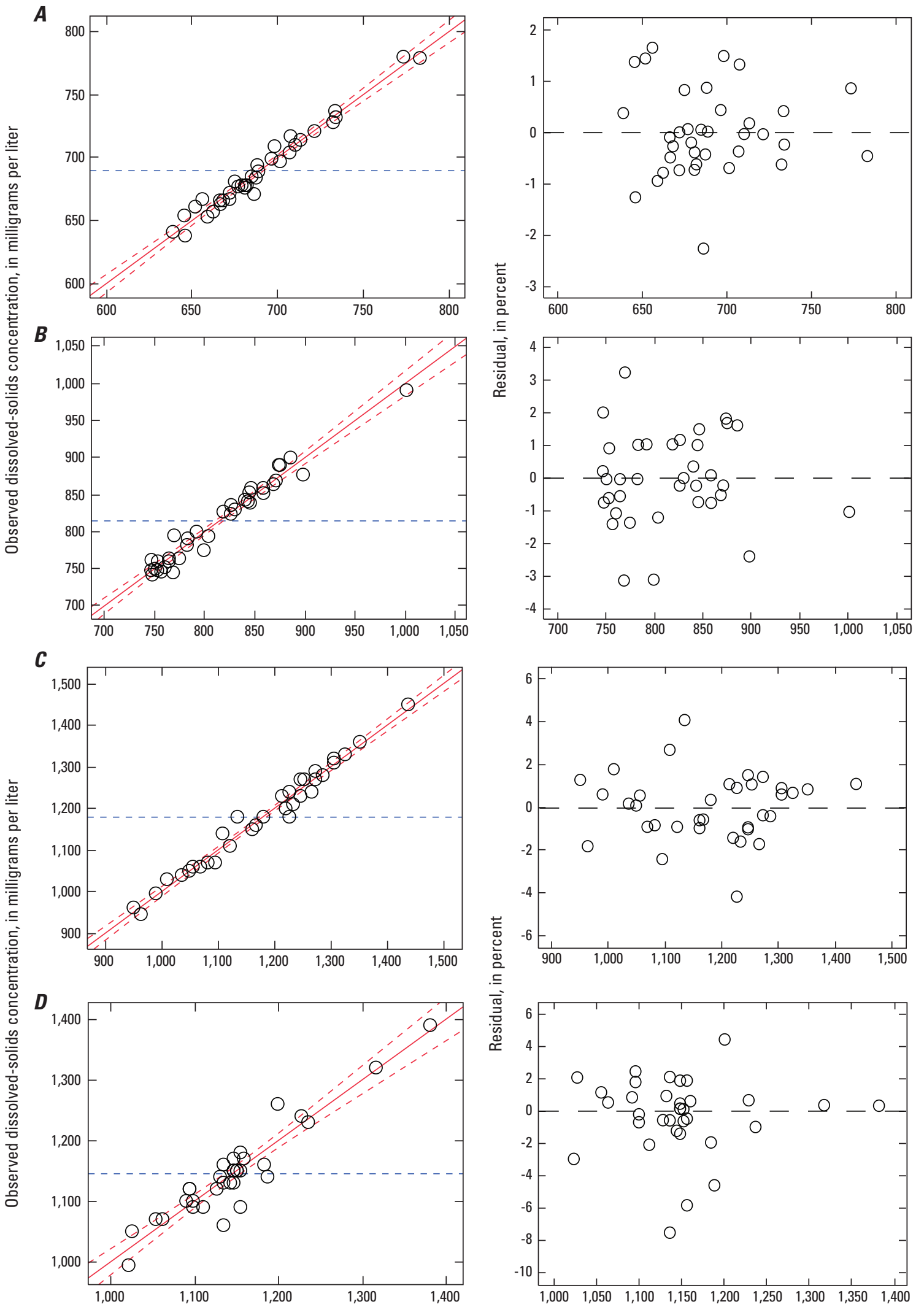

Figure 20. Plots of modeled versus observed regression with 1:1 line and plots of modeled versus observed residuals at stations: $A$, 09429490 (Colorado River above Imperial Dam, Arizona-California), $B$, 09522005 (Colorado River below Cooper wasteway near Yuma, Arizona), $C$, 09534000 (Yuma Main Drain above ArizonaSonora boundary), and $D, 09534550$ (242 lateral above Main Drain at Arizona-Sonora boundary).

Modeled dissolved-solids concentration, in milligrams per liter 
sample sizes were relatively small ( 34 to 36 samples) and the range of measured specific conductance was not completely represented in the dissolved-solids samples collected. Plots of the observed and modeled dissolved solids showed generally good fits and equally distributed residuals. The $242 \mathrm{~L}$ plot showed more scatter and less normally distributed residuals. The inconsistent discharge from groundwater sources likely causes high variability in the water chemistry and ultimately in the regression model performance. Continued sampling is needed to represent the higher specific conductance ranges that were observed with the continuous monitor. This likely correlates with lower streamflow, which also needs additional sampling to better represent lower-flow, dissolved-solids concentrations.

\section{Summary}

The Colorado River is controlled by an extensive system of dams and canals diverting much of the water in the United States for agricultural and municipal uses. The Water Treaty of 1944 guarantees that 1.5 million acre-feet of Colorado River water is delivered to Mexico from the United States annually. Additionally, the water delivered must meet water-quality criteria as defined in Minute 242. The study developed site-specific relations of specific conductance, water temperature, and dissolved-solids concentrations at four monitoring sites in the Yuma area between Imperial Dam and the United States-Mexico southerly international boundary to predict dissolved-solids concentrations using surrogate regression-modeling approaches. The surrogate models that were developed and real-time estimates of dissolved solids in water will aide water managers in making timely decisions on water operations in order to better meet the water-quality obligations of Minute 242 .

Instream specific conductance and water temperature data were recorded every 15 minutes at 4 sites: (1) the Colorado River above Imperial Dam, (2) the Colorado River below Cooper wasteway, (3) Yuma Main Drain above ArizonaSonora boundary, and (4) the 242 lateral above Main Drain at Arizona-Sonora boundary. Discrete water-quality samples were collected at each site either biweekly or monthly over the period January 2017 to March 2019. Dissolved-solids concentration, or salinity, was computed for each sample as the sum concentration of 11 major elements. Multiple linearregression models relating specific conductance (and other factors) to dissolved-solids concentration were developed independently for all four sites based on the data collected.

Instream specific conductance for all sites from January 2017 to March 2019 ranged from 966 to 3,030 microsiemens per centimeter at 25 degrees Celsius. Dissolved-solids concentrations from discrete samples ranged from 690 to 2,580 milligrams per liter $(\mathrm{mg} / \mathrm{L})$ during the same period. Streamflow ranged from 0 to 11,700 cubic feet per second for all sites. All sites were evaluated for representative stream conditions relative to the cross section and the placement of the multi-parameter sensor. All but one site, Colorado River below Cooper wasteway, had consistently well mixed instream conditions, and specific conductance was well represented by the multi-parameter probe. Inflows from the Pilot Knob Hydro-electric Plant to the Colorado River 1.5 miles upstream from Cooper wasteway resulted in a poorly mixed stream cross section at the station when the powerplant was operational and releasing water to the river. During periods of poor mixing the specific conductance values from the instream monitor were always greater than the mean channel specific conductance values, as determined from discrete samples. A correction factor based on individual discrete sample data was developed and applied over time in order for the in-place specific conductance values to better represent the mean channel conditions.

The multiple linear-regression models explained 87.6 to 96.9 percent of the variation in dissolved solids, and the root mean square error ranged between about 6 and $27 \mathrm{mg} / \mathrm{L}$. Specific conductance was the primary factor at all four sites and explained 87.6 to 94 percent of variation in dissolved solids concentrations. Water temperature, as an indicator of seasonal variations, was determined to be a statistically significant secondary factor at both Colorado River above Imperial Dam and Colorado River below Cooper wasteway that explained an additional 6.9 and 2.1 percent of variation in dissolved solids, respectively. The multiple-linear regression models represented between 85 and 95 percent of all the continuous specific conductance values measured at the four sites during the study.

\section{References Cited}

Colorado River Basin Salinity Control Forum, 2017, Water quality standards for salinity, Colorado River system, 2017 review: Colorado River Basin Salinity Control Forum, 108 p., at http://www.coloradoriversalinity.org/docs/2017\%20 Review\%20-\%20FINAL.pdf.

Colorado River Basin Water Supply and Demand Study Team, 2012, Colorado River Basin water supply and demand study technical memorandum C-Quantification of Water Demand Scenarios: Bureau of Reclamation, 61 p., at https:// www.usbr.gov/lc/region/programs/crbstudy/TechMemoC/ TMCreport.pdf.

Dickinson, J.E., Land, M., Faunt, C.C., Leake, S.A., Reichard, E.G., Fleming, J.B., and Pool, D.R., 2006, Hydrogeologic framework refinement, ground-water flow and storage, water-chemistry analyses, and water-budget components of the Yuma area, southwestern Arizona and southeastern California: U.S. Geological Survey Scientific Investigations Report 2006-5135, 90 p.

Fishman, M.J., ed., 1993, Methods of analysis by the U.S. Geological Survey National Water-Quality Laboratorydetermination of inorganic and organic constituents in water and fluvial sediments: U.S. Geological Survey Open-File Report 93-125, $217 \mathrm{p}$. 
Fishman, M.J., and Friedman, L.C., eds., 1989, Methods for determination of inorganic substances in water and fluvial sediments: U.S. Geological Survey Techniques of WaterResources Investigations, book 5, chap. A1, 545 p.

Helsel, D.R., Hirsch, R.M., Ryberg, K.R., Archfield, S.A., and Gilroy, E.J., 2020, Statistical methods in water resources: U.S. Geological Survey Techniques and Methods, book 4, chapter A3, 458 p., https://doi.org/10.3133/tm4a3. [Supersedes USGS Techniques of Water-Resources Investigations, book 4, chapter A3, version 1.1.]

Hem, J.D., 1985, Study and interpretation of the chemical characteristics of natural water ( $3 \mathrm{~d}$ ed.): U.S. Geological Survey Water Supply Paper 2254, 263 p., at https://pubs. er.usgs.gov/publication/wsp2254.

Hermosillo, E., and Cederberg, J.R., 2019, Supplemental streamflow, quality-assurance, and dissolved-solids concentration datasets used for regression model development at four sites in the Yuma area, Arizona and California, January 2017 through March 2019: U.S. Geological Survey data release, https://doi.org/10.5066/ p9SMK908.

Imperial Irrigation District, 2019, Imperial Dam: Imperial Dam Irrigation District, accessed May 14, 2019, at https://www.iid.com/water/water-transportation-system/ colorado-river-facilities/imperial-dam.

International Boundary and Water Commission, United States and Mexico, 1946, Utilization of waters of the Colorado and Tijuana Rivers and of the Rio Grande-Treaty between the United States and Mexico: Washington, D.C., U.S. Government Printing Office, 57 p., at https://www.ibwc. gov/Files/1944Treaty.pdf.

International Boundary and Water Commission, 1973, Permanent and definitive solution to the international problem of the salinity of the Colorado River: International Boundary and Water Commission, Minute no. 242, August 30, 1973, at http://www.ibwc.gov/Files/Minutes/Min242.pdf.

International Boundary and Water Commission, 2006, Flow of the Colorado River and other western boundary streams and related data: International Boundary and Water Commission, at https://www.ibwc.gov/wad/Colorado River/2006.pdf.

International Boundary and Water Commission, 2017, Extension of cooperative measures and adoption of a binational water scarcity contingency plan in the Colorado River Basin: International Boundary and Water Commission, Minute 323, September 21, 2017, at https:/www.ibwc.gov/ Files/Minutes/Min323.pdf.

Mueller, D.K., Schertz, T.L., Martin, J.D., and Sandstrom, M.W., 2015, Design, analysis, and interpretation of field quality-control data for water-sampling projects: U.S. Geological Survey Techniques and Methods, book 4, chap. C4, 54 p., at http://dx.doi.org/10.3133/tm4C4.
Olmsted, F.H., O.J. Loeltz, and Irelan, B., 1973, Geohydrology of the Yuma Area, Arizona and California: U.S. Geological Survey Professional Paper 486-H, 227 p., at https://pubs. usgs.gov/pp/0486h/report.pdf.

Owen-Joyce, S. J. and Raymond, L. H., 1996, An accounting system for water and consumptive use along the Colorado River, Hoover Dam to Mexico: U.S. Geological Survey Water Supply Paper 2407, 94 p., at https://pubs.er.usgs.gov/ publication/wsp2407.

Patton, C. J. and Kryskalla, J. R., 2011, Colorimetric determination of nitrate plus nitrite in water by enzymatic reduction, automated discrete analyzer methods: U.S. Geological Survey Techniques and Methods, book 5, chap. B8, 34 p., at https://pubs.usgs.gov/tm/05b08/.

Pellerin, B.A., Bergamaschi, B.A., Downing, B.D., Saraceno, J.F., Garrett, J.A., and Olsen, L.D., 2013, Optical techniques for the determination of nitrate in environmental watersGuidelines for instrument selection, operation, deployment, maintenance, quality assurance, and data reporting: U.S. Geological Survey Techniques and Methods 1-D5, 37 p., at https://pubs.usgs.gov/tm/01/d5/.

Phoenix, Arizona Weather Forecast Office, 2019, Monthly climate normal (1981-2010) for YUMA WSO AP, Ariz.: National Weather Service, accessed July 2, 2019, at https:// w2.weather.gov/climate/xmacis.php?wfo=psr.

Rasmussen, P.P., Gray, J.R., Glysson, G.D., and Ziegler, A.C., 2009, Guidelines and procedures for computing time-series suspended-sediment concentrations and loads from in-stream turbidity-sensor and streamflow data: U.S. Geological Survey Techniques and Methods, book 3, chap. C4, 53 p., at https://pubs.usgs.gov/tm/tm3c4/.

SAS Institute Inc., 2015, JMP 12 Online Documentation: Cary, North Carolina, SAS Institute Inc., at https:/www. jmp.com/support/help/index12.shtml.

Shoda, M.E., Lathrop, T.R., and Risch, M.R., 2015, Realtime, continuous water-quality monitoring in Indiana and Kentucky: U.S. Geological Survey Fact Sheet 2015-3041, 4 p., at https://doi.org/10.3133/fs20153041.

U.S. Geological Survey, 2012, The national field manual for the collection of water-quality data (version 7): U.S. Geological Survey Techniques and Method, book 9, chaps. A1-A9, accessed April 5, 2013, at https://water.usgs.gov/ owq/FieldManual/.

U.S. Geological Survey, 2019, USGS water data for the Nation: U.S. Geological Survey National Water Information System database, accessed August, 30, 2019, at http://doi.org/10.5066/F7P55KJN.

Wagner, R.J., Boulger, R.W., Jr., Oblinger, C.J., and Smith, B.A., 2006, Guidelines and standard procedures for continuous water-quality monitors - Station operation, record computation, and data reporting: U.S. Geological Survey Techniques and Methods 1-D3, 51 p., plus 8 attachments, accessed February 7, 2019, at https://pubs.usgs.gov/ $\mathrm{tm} / 2006 / \mathrm{tm} 1 \mathrm{D} 3 /$. 
Moffett Field Publishing Service Center, California Manuscript approved for publication July 27, 2021 Edited by Phil A. Frederick

Layout and design by Kimber Petersen

Cartography and illustration support by JoJo Mangano 


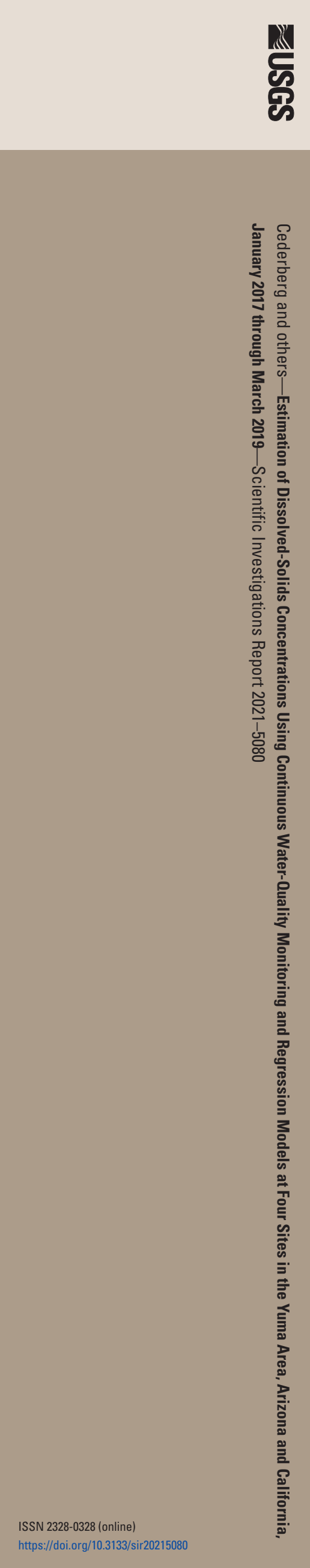

